\title{
Reactive uptake of ammonia to secondary organic aerosols: kinetics of organonitrogen formation
}

\author{
Y. Liu ${ }^{1,2}$, J. Liggio ${ }^{1}$, R. Staebler ${ }^{1}$, and S.-M. Li $^{1}$ \\ ${ }^{1}$ Atmospheric Science and Technology Directorate, Science and Technology Branch, Environment Canada, \\ Toronto, M3H 5T4, Canada \\ ${ }^{2}$ State Key Joint Laboratory of Environmental Simulation and Pollution Control, Research Center for Eco-Environmental \\ Sciences, Chinese Academy of Sciences, Beijing, 100085, China \\ Correspondence to: J. Liggio (john.liggio@ec.gc.ca)
}

Received: 21 May 2015 - Published in Atmos. Chem. Phys. Discuss.: 25 June 2015

Revised: 20 November 2015 - Accepted: 24 November 2015 - Published: 9 December 2015

\begin{abstract}
As a class of brown carbon, organonitrogen compounds originating from the heterogeneous uptake of $\mathrm{NH}_{3}$ by secondary organic aerosol (SOA) have received significant attention recently. In the current work, particulate organonitrogen formation during the ozonolysis of $\alpha$-pinene and the $\mathrm{OH}$ oxidation of $m$-xylene in the presence of ammonia (34$125 \mathrm{ppb}$ ) was studied in a smog chamber equipped with a high resolution time-of-flight aerosol mass spectrometer and a quantum cascade laser instrument. A large diversity of nitrogen-containing organic (NOC) fragments was observed which were consistent with the reactions between ammonia and carbonyl-containing SOA. Ammonia uptake coefficients onto SOA which led to organonitrogen compounds were reported for the first time, and were in the range of $\sim 10^{-3}$ $10^{-2}$, decreasing significantly to $<10^{-5}$ after $6 \mathrm{~h}$ of reaction. At the end of experiments $(\sim 6 \mathrm{~h})$ the NOC mass contributed $8.9 \pm 1.7$ and $31.5 \pm 4.4 \mathrm{wt} \%$ to the total $\alpha$-pineneand $m$-xylene-derived SOA, respectively, and $4-15 \mathrm{wt} \%$ of the total nitrogen in the system. Uptake coefficients were also found to be positively correlated with particle acidity and negatively correlated with $\mathrm{NH}_{3}$ concentration, indicating that heterogeneous reactions were responsible for the observed NOC mass, possibly limited by liquid phase diffusion. Under these conditions, the data also indicate that the formation of NOC can compete kinetically with inorganic acid neutralization. The formation of NOC in this study suggests that a significant portion of the ambient particle associated $\mathrm{N}$ may be derived from $\mathrm{NH}_{3}$ heterogeneous reactions with SOA. NOC from such a mechanism may be an important and unaccounted for source of PM associated nitrogen. This
\end{abstract}

mechanism may also contribute to the medium or long-range transport and wet/dry deposition of atmospheric nitrogen.

\section{Introduction}

Black carbon $(\mathrm{BC})$ and brown carbon $(\mathrm{BrC})$ are the most abundant and effective light absorbing components in atmospheric particles (IPCC, 2013; Andreae and Gelencsér, 2006). While BC has been extensively studied (Cappa et al., 2012; Bond et al., 2013), BrC is currently receiving significant attention from the atmospheric chemistry community as it is often more abundant than BC in the atmosphere, and has the potential to be an important climate forcing agent via direct absorption of light (Laskin et al., 2015). BrC refers to organic matter in atmospheric particles that absorb light with a strong wavelength dependence (Andreae and Gelencsér, 2006; Alexander et al., 2008; Moise et al., 2015). It exists in various forms, such as soil-derived humic materials, humic-like substances (HULIS), organic materials from combustion processes, bioaerosols (Andreae and Gelencsér, 2006; Salma et al., 2010) and secondary formation in the atmosphere (Laskin et al., 2015; Zarzana et al., 2012; Nguyen et al., 2013; Powelson et al., 2014). Although the chemical composition of $\mathrm{BrC}$ is highly complex, light absorption by $\mathrm{BrC}$ in the ultraviolet-visible region, quantified by the mass absorption coefficient (MAC) (typically in the range of $0.001-0.1 \mathrm{~m}^{2} \mathrm{~g}^{-1}$ at $500 \mathrm{~nm}$ of wavelength (Updyke et al., 2012), is ascribed to the $\pi-\pi *$ and $n-\pi *$ bond transitions of electrons in the chemicals present. The $\pi-\pi^{*}$ transition 
is usually observed in species with unsaturated bonds, while $\mathrm{n}-\pi *$ transitions are relevant to heteroatoms coupled to unsaturated bonds.

Primary emissions of biomass-burning particles are regarded as an important source of $\mathrm{BrC}$ (Saleh et al., 2013; Andreae and Gelencsér, 2006) since polycyclic aromatic hydrocarbons (PAHs), nitro-PAHs, oxy-PAHs and other aromatic hydrocarbons, and therefore unsaturated bonds, are abundant in these combustion particles (Andrade-Eiroa et al., 2010; Kinsey et al., 2011; Souza et al., 2014). Secondary formation of particulate organics have also recently been considered another possible source of $\mathrm{BrC}$ through heterogeneous or multiphase chemical reactions (Updyke et al., 2012; Zarzana et al., 2012; Nguyen et al., 2013; Powelson et al., 2014), in which heteroatoms including $\mathrm{O}, \mathrm{S}$ and $\mathrm{N}$ can be introduced into the particulate matter via a variety of precursors. For example, as characteristic components of HULIS (Nguyen et al., 2014, 2012), organosulfates and organonitrates have been observed in both laboratory generated (Liggio and Li, 2006b; Iinuma et al., 2009; Russell et al., 2011; Darer et al., 2011) and ambient organic particles (Hawkins et al., 2010; Surratt et al., 2006; Russell et al., 2011). Oxygen- and nitrogen-containing oligomers of high molecular weight have also been identified in secondary organic aerosols (SOA) (Kalberer et al., 2004).

$\mathrm{N}$-containing organic compounds (NOC) are an important class of heteroatom-containing $\mathrm{BrC}$ compounds and can account for an appreciable fraction of organic aerosol mass (Beddows et al., 2004; Cheng et al., 2006; Kourtchev et al., 2014) which has been mainly attributed to biomassburning and cooking emissions (Cheng et al., 2006). As summarized in detail in a recent review paper (Zhang et al., 2015), heterogeneous reactions, which include acid-base reactions between amines and organic acids as well as acidcatalyzed reactions of carbonyl groups in OA with primary and secondary amines, are increasingly being considered an important source of particle-bound organonitrogen compounds. For example, acid-base reactions between ammonia or amines and acid moieties (Liu et al., 2012b; Kuwata and Martin, 2012; Zhang et al., 2015) or exchange reactions of amines with inorganic ammonium salts (Chan and Chan, 2012; Bzdek et al., 2010; Qiu et al., 2011; Liu et al., 2012a) can lead to the formation of particle-bound ammonium salts. Reaction to form Schiff base and/or Mannich reaction between $\mathrm{NH}_{3}$, ammonium salts or amines with carbonyl functional groups in particles can also form organonitrogen compounds (Zhang et al., 2015), in which $\mathrm{N}$ atoms can be coupled to double bonds (imines) and act as effective chromophores since both $\pi-\pi^{*}$ and $n-\pi *$ transitions are possible (Nguyen et al., 2013). It has also been proposed that Mannich reactions may be a possible formation mechanism for the high-molecular weight nitrogen-containing organic species observed in ambient particles (X. F. Wang et al., 2010). Although it has not been confirmed with ambient data, the formation of light absorbing compounds has been inferred in laboratory studies during reactions between glyoxal, methylgloxyal and primary amines glycine, methylamine and ammonium (Zarzana et al., 2012; Yu et al., 2011; Powelson et al., 2014; A. K. Y. Lee et al., 2013; Trainic et al., 2011). Visible light absorption has also been observed from the reactions between $\mathrm{O}_{3} / \mathrm{OH}$ initiated biogenic and anthropogenic SOA and $\mathrm{NH}_{3}$ (Updyke et al., 2012; Nguyen et al., 2013; H. J. Lee et al., 2013; Bones et al., 2010). Using high resolution time-of-flight aerosol mass spectrometry (HR-ToF-AMS) and desorption electrospray ionization mass spectrometry (DESI-MS), characteristic fragments containing nitrogen $\left(\mathrm{C}_{x} \mathrm{H}_{y} \mathrm{~N}_{n}\right.$ and $\left.\mathrm{C}_{x} \mathrm{H}_{y} \mathrm{O}_{z} \mathrm{~N}_{n}\right)$ from the above reactions have been identified (Galloway et al., 2009; Laskin et al., 2010; A. K. Y. Lee et al., 2013). Recent studies have found that $\mathrm{BrC}$ produced via such reactions is unstable with respect to degradation by oxidants (Sareen et al., 2013) and sunlight (Lee et al., 2014; Zhao et al., 2015). Regardless, NOC are likely to have very interesting chemical properties and atmospheric implications.

In addition to the noted role of organonitrogen in $\mathrm{BrC}$, heterogeneously formed organonitrogen may be an important nutrient to ecosystems via nitrogen $(\mathrm{N})$ deposition from the atmosphere (Liu et al., 2013). Heterogeneous reactions leading to NOC can be considered a process whereby gas-phase nitrogen compounds such as $\mathrm{NH}_{3}$ or amines with short lifetimes (via deposition) (Liggio et al., 2011) are transformed to particle-phase nitrogen compounds with increased atmospheric lifetimes. The subsequent transport and deposition of particle-phase organonitrogen compounds (rather than gasphase $\mathrm{N}$ ) may have an impact on regional nitrogen cycles by altering $\mathrm{N}$ deposition patterns. However, this process has generally not been considered in current deposition models (García-Gómez et al., 2014) due to limited knowledge on the formation kinetics and mechanisms of NOC formation from heterogeneous reactions.

While reactions of amines have been implicated as a source of particulate-phase reduced nitrogen (Zarzana et al., 2012), their ambient gaseous concentrations are typically low (Cornell et al., 2003). $\mathrm{NH}_{3}$ is the most abundant form of gas-phase reduced nitrogen in the atmosphere with global emissions estimated at greater than $33 \mathrm{Tg}(\mathrm{N}) \mathrm{yr}^{-1}$ (Reis et al., 2009) and typical ambient concentration of several ppbv (Cornell et al., 2003; Heald et al., 2012). As qualitatively confirmed by mass spectrometry in various experiments (Updyke et al., 2012; Nguyen et al., 2013; H. J. Lee et al., 2013; Bones et al., 2010), reactions between $\mathrm{NH}_{3}$ and $\mathrm{OA}$ are possible in the atmosphere leading to particulate reduced nitrogen. In order to assess and model the impacts of the reaction to form Schiff base, Mannich or other NOC forming reactions (via $\mathrm{NH}_{3}$ ) on the radiative forcing potentials of ambient SOA and N-deposition, the kinetics of such reactions are required, and yet they remain largely unknown. To the best of our knowledge, there is only one paper which reported the formation rate constant of imidazole-2-caroxaldehyde (IC) to be $(2.01 \pm 0.40) \times 10^{-12} \mathrm{M}^{-2} \mathrm{~s}^{-1}$ for the reaction between 
glyoxal and aqueous $\left(\mathrm{NH}_{4}\right)_{2} \mathrm{SO}_{4}$ in an effort to simulate cloud processing (Yu et al., 2011).

In this study, heterogeneous reactive uptake coefficients $(\gamma)$ for $\mathrm{NH}_{3}$ onto laboratory SOA, which lead to the formation of particulate NOC, were derived using a smog chamber coupled to a HR-ToF-AMS. The influence of VOC precursors, seed particle acidity/composition and gaseous $\mathrm{NH}_{3}$ concentration on the obtained uptake coefficients of $\mathrm{NH}_{3}$ is also investigated. Finally, the implications of the kinetics on atmospheric $\mathrm{BrC}$ and $\mathrm{N}$-deposition are also discussed.

\section{Experimental details}

\subsection{Chamber experiments}

Experiments were performed in a $9 \mathrm{~m}^{3}$ cylindrical smog chamber, which has been described in detail by Bunce et al. (1997). Briefly, this reactor is constructed with $50 \mu \mathrm{m}$ FEP Teflon film and housed in an air-conditioned room $(295 \pm 2 \mathrm{~K})$. The surface-to-volume $(S / V)$ ratio is $2.7 \mathrm{~m}^{-1}$. A total of 24 black light lamps (Sylvania, F40/350BL) were installed outside the reactor for photochemical reactions. Before each experiment, the chamber was cleaned by irradiation (300-400 nm, $350 \mathrm{~nm}$ peak wavelength) for $8 \mathrm{~h}$ followed by continuous flushing with zero air for $24 \mathrm{~h}$, after which the concentration of particles and ammonia was $<1$ particle $\mathrm{cm}^{-3}$ and $\sim 5 \mathrm{ppbv}$, respectively.

A summary of initial experimental conditions is given in Table 1. $\mathrm{Na}_{2} \mathrm{SO}_{4} / \mathrm{H}_{2} \mathrm{SO}_{4}$ particles were generated as seeds via atomization (model 3706, TSI), dried through a diffusion drier, and size-selected with a differential mobility analyzer (DMA) (model, 3081, TSI) to have a mode mobility diameter $\left(D_{\mathrm{m}}\right)$ of $\sim 90 \mathrm{~nm}$. A high concentration of $\mathrm{Na}_{2} \mathrm{SO}_{4} / \mathrm{H}_{2} \mathrm{SO}_{4}$ seeds $\left(\sim 5000\right.$ particle $\left.\mathrm{cm}^{-3}\right)$ was added into the chamber to suppress new particle formation from the added VOC precursor and oxidant. As shown in Fig. S2 in the Supplement, new particle formation was suppressed during subsequent SOA formation. $\alpha$-pinene or $m$-xylene (Sigma Aldrich) were added into the chamber via a syringe which was purged with zero air prior to reaction. The VOC concentrations were measured online with a high resolution time-of-flight proton transfer reaction mass spectrometer (HR-ToF-PTRMS, Ionic Analytic). SOA was formed via the oxidation of the VOCs by $\mathrm{O}_{3}$ or $\mathrm{OH}$. The concentration, size and composition of SOA coated on the seed particles were measured with a scanning mobility particle sizer (SPMS, TSI) and a HRToF-AMS (Aerodyne) (DeCarlo et al., 2006) operated alternately in both V- and W-mode. HR-ToF-AMS data were analyzed with the software PIKA 1.12 (DeCarlo et al., 2006; Aiken et al., 2007). The concentration of NOC was determined by fitting peaks including those from the $\mathrm{NH}_{x}, \mathrm{NO}_{x}$, $\mathrm{C}_{x} \mathrm{H}_{y} \mathrm{~N}_{n}, \mathrm{C}_{x} \mathrm{H}_{y} \mathrm{ON}_{n}$ and $\mathrm{C}_{x} \mathrm{H}_{y} \mathrm{O}_{2} \mathrm{~N}_{n}$ fragment groups. Particle wall loss was accounted for by normalizing SOA and NOC concentrations to the sulfate seed signal from the HR-
ToF-AMS. It should be noted that the NOC concentration may be underestimated in this study since one cannot resolve all the nitrogen containing fragments that may exist, and since some of the NOCs may fragment into masses that do not contain nitrogen and thus are quantified as organic. Furthermore, the relative ionization efficiency (RIE) for the NOC fragments was assumed to be equivalent to the remainder of the organics (1.4), since a RIE value for NOC is unknown. This may introduce an additional uncertainty to the quantitation of NOC. It should also be pointed out that some NOC species may be formed through the pyrolysis/ionization processes occurring in the ionization region. This would result in a positive uncertainty for NOC measurements in this study, although it is expected to be small.

$\mathrm{O}_{3}$ was generated by passing zero air through an $\mathrm{O}_{3}$ generator (OG-1, PCI Ozone Corp.) and measured with an $\mathrm{O}_{3}$ monitor (model 205, 2B Technologies). OH was produced by photolysis of $\mathrm{H}_{2} \mathrm{O}_{2}$ (K. Wang et al., 2010; Donahue et al., 2012), which was added by bubbling zero air through a $30 \%$ $\mathrm{H}_{2} \mathrm{O}_{2}$ solution (Sigma Aldrich). Details regarding the $\mathrm{OH}$ concentration determination and the oxidant levels during these experiments are described further in the Supplement. $\mathrm{NH}_{3}$ from a standard cylinder was added into the chamber though a passivated mass flow controller. $\mathrm{NH}_{3}$ concentration in the chamber was measured with a quantum cascade laser (QCL, Aerodyne), whose principle of operation has been described elsewhere (Kosterev et al., 2002).

Unfortunately, the $\mathrm{NH}_{3}$ background in the dry chamber was consistently at $\sim 5 \mathrm{ppbv}$ (after cleaning), increasing to a reproducible $\sim 35 \mathrm{ppbv}$ after humidifying to $50 \% \mathrm{RH}$. While this limited the ability to perform experiments in the complete absence of ammonia, it did not preclude the derivation of kinetics at the lowest concentration ( $35 \mathrm{ppbv})$ and higher attained by further additions of ammonia. In some experiments, external $\mathrm{NH}_{3}$ was added to the reactor after $\sim 6 \mathrm{~h}$ of reaction to measure the uptake kinetics of $\mathrm{NH}_{3}$ by relatively aged SOA. All experiments were conducted at $50 \pm 2 \% \mathrm{RH}$, with zero air provided by an AADCO-737 generator (AADCO Instruments Inc.).

The presence of NOC in the SOA particles was also confirmed by Fourier Transform Infrared (FTIR) Spectroscopy. SOA was collected on a silver membrane filter $(0.2 \mu \mathrm{m}$, $47 \mathrm{~mm}$, Sterlitech; stainless steel filter holder), which has a wide IR window in the range of $650-4000 \mathrm{~cm}^{-1}$. A second filter placed behind the first one was used as a reference sample for IR measurements. The IR spectra were recorded with a mercury cadmium telluride (MCT) detector at a resolution of $4 \mathrm{~cm}^{-1}$ for 200 scans in diffuse reflectance infrared Fourier transform spectroscopy (DRIFTS) mode, using an iS50 spectrometer (Nicolet).

\subsection{Derivation of kinetics}

Reactive uptake coefficients $(\gamma)$ of $\mathrm{NH}_{3}$ to form $\mathrm{NOC}$ were calculated based upon the measured concentration time se- 
Table 1. Initial gaseous and particle phase experimental conditions.

\begin{tabular}{|c|c|c|c|c|c|c|c|c|}
\hline $\begin{array}{l}\text { Exp. } \\
\text { No. }^{\text {a }}\end{array}$ & VOC & $\begin{array}{l}C_{\text {VOC }} \\
(\mathrm{ppbv})\end{array}$ & $\begin{array}{r}C_{\mathrm{O}_{3}} \\
\text { (ppbv) }\end{array}$ & $\begin{array}{r}C_{\mathrm{OH}} \\
\left(\text { molecules } \mathrm{cm}^{-3}\right)\end{array}$ & $\begin{array}{r}C_{\mathrm{NH} 3} \\
(\mathrm{ppbv})\end{array}$ & $\begin{array}{r}\mathrm{H}_{2} \mathrm{SO}_{4} / \mathrm{Na}_{2} \mathrm{SO}_{4} \\
\left(\mathrm{~mol} \mathrm{~mol}^{-1}\right)\end{array}$ & $\begin{array}{r}c_{\mathrm{P}} \\
\left(\text { particles } \mathrm{cm}^{-3}\right)\end{array}$ & $\begin{array}{r}M_{\mathrm{O}}^{\mathrm{b}} \\
\left(\mu \mathrm{g} \mathrm{m}^{-3}\right)\end{array}$ \\
\hline $\mathrm{P} 1$ & $\alpha$-pinene & 11.7 & 30.7 & $2.85 \times 10^{6}$ & 50.7 & 0.76 & 5863 & 11.2 \\
\hline $\mathrm{P} 2$ & $\alpha$-pinene & 16.9 & 30.2 & $1.77 \times 10^{6}$ & 66.6 & 1.19 & 5627 & 16.4 \\
\hline P3 & $\alpha$-pinene & 22.1 & 30.0 & $3.41 \times 10^{6}$ & 34.1 & 2.12 & 5377 & 23.5 \\
\hline P4 & $\alpha$-pinene & 13.6 & 31.2 & $2.81 \times 10^{6}$ & 40.6 & 1.71 & 4761 & 13.6 \\
\hline P5 & $\alpha$-pinene & 13.3 & 33.4 & $2.22 \times 10^{6}$ & 49.7 & 0 & 3836 & 5.8 \\
\hline P6 & $\alpha$-pinene & 13.6 & 33.3 & $1.57 \times 10^{6}$ & 40.8 & 1.68 & 5276 & 13.6 \\
\hline B7 & - & 0 & 31.8 & - & 44.0 & 1.68 & 4656 & 0.4 \\
\hline P8 & $\alpha$-pinene & 11.9 & 33.1 & $1.87 \times 10^{6}$ & 34.1 & 1.95 & 4632 & 12.8 \\
\hline P9 & $\alpha$-pinene & 11.2 & 31.0 & $2.18 \times 10^{6}$ & 42.6 & 1.95 & 5554 & 10.4 \\
\hline $\mathrm{P} 10$ & $\alpha$-pinene & 11.3 & 31.0 & $3.01 \times 10^{6}$ & 56.6 & 1.95 & 5437 & 15.4 \\
\hline P11 & $\alpha$-pinene & 11.2 & 31.0 & $2.41 \times 10^{6}$ & 63.9 & 1.95 & 5464 & 14.6 \\
\hline P12 & $\alpha$-pinene & 12.8 & 30.9 & $3.47 \times 10^{6}$ & 101.5 & 1.95 & 5495 & 20.6 \\
\hline P13 & $\alpha$-pinene & 10.4 & 31.2 & $3.41 \times 10^{6}$ & 75.1 & 1.95 & 5402 & 16.6 \\
\hline P14 & $\alpha$-pinene & 10.9 & 29.2 & $3.49 \times 10^{6}$ & 61.9 & 1.95 & 5809 & 15.6 \\
\hline M15 & $m$-xylene & 21.6 & - & $1.74 \times 10^{6}$ & 49.4 & 1.95 & 4910 & 6.4 \\
\hline M16 & $m$-xylene & 25.0 & - & $1.82 \times 10^{6}$ & 66.2 & 1.95 & 4966 & 6.8 \\
\hline M17 & $m$-xylene & 23.3 & - & $1.78 \times 10^{6}$ & 86.2 & 1.95 & 4948 & 6.0 \\
\hline M18 & $m$-xylene & 21.1 & - & $1.40 \times 10^{6}$ & 97.9 & 1.95 & 4612 & 5.4 \\
\hline M19 & $m$-xylene & 22.1 & - & $1.93 \times 10^{6}$ & 104.4 & 1.95 & 4918 & 5.8 \\
\hline M20 & $m$-xylene & 19.7 & - & $1.31 \times 10^{6}$ & 125.7 & 1.95 & 5248 & 5.6 \\
\hline
\end{tabular}

${ }^{a} \mathrm{P}, \mathrm{B}$ and $\mathrm{M}$ represent $\alpha$-pinene, blank and $m$-xylene, respectively. Experiments performed at $\mathrm{RH}=50 \pm 1 \% ; T=295 \pm 2 \mathrm{~K} .{ }^{\mathrm{b}}$ Organics after $6 \mathrm{~h}$ of exposure.

ries of nitrogen atom $(\mathrm{N})$ mass derived from the HR-ToFAMS fragment families of $\mathrm{C}_{x} \mathrm{H}_{y} \mathrm{~N}_{n}, \mathrm{C}_{x} \mathrm{H}_{y} \mathrm{ON}_{n}, \mathrm{C}_{x} \mathrm{H}_{y} \mathrm{O}_{2} \mathrm{~N}_{n}$, $\mathrm{NH}_{x}$ and $\mathrm{NO}_{x}$ using an uptake model that has been described in detail previously (Liggio et al., 2005b; Liggio and $\mathrm{Li}, 2006 \mathrm{a}$ ). Briefly, the change in the mass of $\mathrm{N}$ (within the NOC) added to a particle exposed to $\mathrm{NH}_{3}$ as a function of time can be described by

$$
\frac{\mathrm{d} m_{\mathrm{N}}}{\mathrm{d} t}=\gamma_{\mathrm{obs}} \pi a^{2}<c>c_{\mathrm{NH}_{3}} F_{\mathrm{h}}
$$

where $a,\langle c\rangle$ and $c_{\mathrm{NH}_{3}}$ are the particle radius, mean molecular speed and gas-phase concentration of $\mathrm{NH}_{3}$, respectively; $\gamma_{\mathrm{obs}}$ is the observed uptake coefficient of $\mathrm{NH}_{3}$ to form NOC (specifically the $\mathrm{N}$ in the NOC); $F_{\mathrm{h}}$ is a heterogeneous mass factor that accounts for the loss of hydrogen in ammonia as it reacts heterogeneously to form particulate phase NOC. We assume $F_{\mathrm{h}}$ is equal to 0.824 (i.e., $\mathrm{N} / \mathrm{NH}_{3}$ ) in this study. From Eq. (1), the $\mathrm{N}$ mass as a function of time is given by the following:

$m_{\mathrm{N}}=\left(\frac{b \pi c_{\mathrm{NH}_{3}}<c>F_{\mathrm{h}}\left(t-t_{0}\right) \gamma_{\mathrm{obs}}+3\left(b m_{0}+d\right)^{\frac{1}{3}}}{3 b^{\frac{1}{3}}}\right)^{3}-\frac{d}{b}$,

where $b=\frac{3}{4 \pi \rho}, d=a_{0}^{3}$ and are constants. The uptake coefficient $(\gamma)$ is derived from a fit of Eq. (2) to the experimental data. Further detail on the derivation and the parameters used in the fits is given in the Supplement. It should be pointed out that the $\mathrm{NH}_{x}^{+}$family $\left(\mathrm{NH}^{+}, \mathrm{NH}_{2}^{+}\right.$and $\left.\mathrm{NH}_{3}^{+}\right)$in the AMS mass spectra may be primarily associated with inorganic ammonium from the neutralization of the $\mathrm{H}_{2} \mathrm{SO}_{4}$ in the seed particle. However, an unknown fraction of the $\mathrm{NH}_{x}^{+}$will arise from the fragmentation of NOC. For this reason, the uptake coefficients have been derived including and excluding the $\mathrm{N}$ mass of $\mathrm{NH}_{x}^{+}$as upper and lower bounds to $\gamma$. The uncertainty in the uptake coefficient will result from the uncertainty in NOC mass concentration measured by the AMS, the concentration of $\mathrm{NH}_{3}$ measured by the QCL and the diameter measured by the SMPS. In this study, the uncertainty is derived from the uptake model parameters based on the measured time series of mass concentration of NOC fragments.

\section{Results and discussion}

\subsection{Identification of NOC}

A typical mass spectrum of SOA from the ozonolysis of $\alpha$-pinene between 4 and $6 \mathrm{~h}$ of reaction in the presence of $40.8 \mathrm{ppbv} \mathrm{NH}_{3}$ (Exp. P6) is shown in Fig. 1. The spectrum is dominated by $\mathrm{C}_{x} \mathrm{H}_{y}$ fragments at $m / z 27\left(\mathrm{C}_{2} \mathrm{H}_{3}^{+}\right)$, $39\left(\mathrm{C}_{3} \mathrm{H}_{3}^{+}\right), 41\left(\mathrm{C}_{3} \mathrm{H}_{5}^{+}\right)$and $53\left(\mathrm{C}_{4} \mathrm{H}_{7}^{+}\right) ; \mathrm{C}_{x} \mathrm{H}_{y} \mathrm{O}$ fragments at $\mathrm{m} / \mathrm{z} 28\left(\mathrm{CO}^{+}\right), 43\left(\mathrm{C}_{2} \mathrm{H}_{3} \mathrm{O}^{+}\right)$and $55\left(\mathrm{C}_{3} \mathrm{H}_{3} \mathrm{O}^{+}\right)$; and 


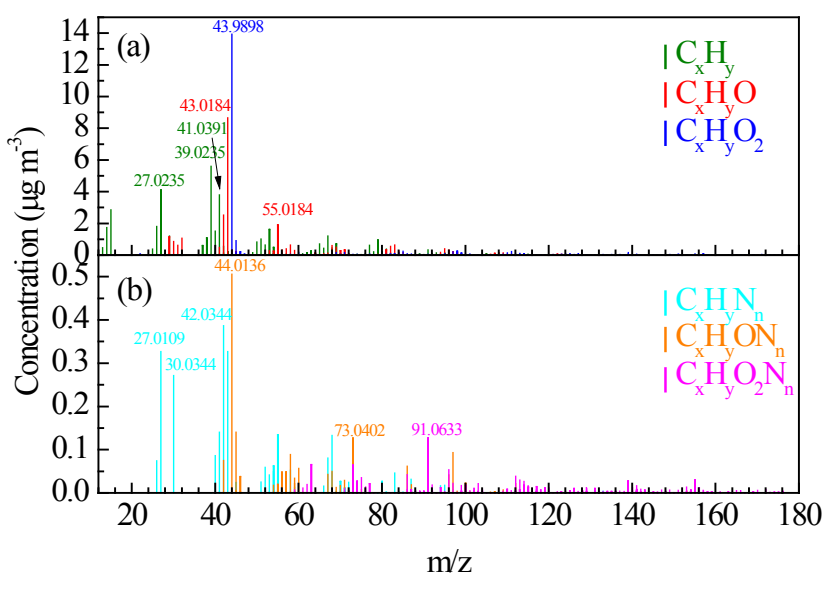

Figure 1. Typical HR-ToF-AMS spectra of (a) non-N-containing fragments and (b) N-containing fragments in SOA formed by $\mathrm{O}_{3}$ oxidation of $\alpha$-pinene in the presence of 40.8 ppbv $\mathrm{NH}_{3}$ (Exp. P6).

$\mathrm{C}_{x} \mathrm{H}_{y} \mathrm{O}_{2}$ fragments at $m / z 44\left(\mathrm{CO}_{2}^{+}\right)$and $45\left(\mathrm{CHO}_{2}^{+}\right)$. The presence of these fragment families and the overall mass spectrum is consistent with previously reported mass spectra of SOA formed from the $\mathrm{O}_{3}$ oxidation of $\alpha$-pinene at low SOA mass loading $\left(<15 \mu \mathrm{g} \mathrm{m}^{-3}\right)$ (Shilling et al., 2009).

In the presence of $\mathrm{NH}_{3}$, a number of $\mathrm{N}$-containing fragments are also observed. The mass spectrum containing $\mathrm{N}$-containing fragments only is shown in Fig. 1b. Strong peaks belonging to the $\mathrm{C}_{x} \mathrm{H}_{y} \mathrm{~N}_{n}$ family of fragments dominate the spectrum at $\mathrm{m} / z 27\left(\mathrm{CHN}^{+}\right), 30\left(\mathrm{CH}_{4} \mathrm{~N}^{+}\right)$, $42\left(\mathrm{C}_{2} \mathrm{H}_{4} \mathrm{~N}^{+}\right), 43\left(\mathrm{C}_{2} \mathrm{H}_{5} \mathrm{~N}^{+}\right), 54\left(\mathrm{C}_{3} \mathrm{H}_{4} \mathrm{~N}^{+}\right), 55\left(\mathrm{C}_{3} \mathrm{H}_{5} \mathrm{~N}^{+}\right)$ and $68\left(\mathrm{C}_{3} \mathrm{H}_{4} \mathrm{~N}_{2}^{+}, \mathrm{C}_{4} \mathrm{H}_{6} \mathrm{~N}^{+}\right)$. Less prevalent peaks from the $\mathrm{C}_{x} \mathrm{H}_{y} \mathrm{ON}_{n}$ and $\mathrm{C}_{x} \mathrm{H}_{y} \mathrm{O}_{2} \mathrm{~N}_{n}$ group of fragments are also observed at $\mathrm{m} / z$. $44\left(\mathrm{CH}_{2} \mathrm{ON}^{+}\right), 45\left(\mathrm{CH}_{3} \mathrm{ON}^{+}\right), 58$ $\left(\mathrm{C}_{2} \mathrm{H}_{4} \mathrm{ON}^{+}\right), 68\left(\mathrm{C}_{3} \mathrm{H}_{2} \mathrm{ON}^{+}\right), 73\left(\mathrm{C}_{2} \mathrm{H}_{5} \mathrm{ON}_{2}^{+}, \mathrm{C}_{3} \mathrm{H}_{7} \mathrm{ON}^{+}\right)$, $86\left(\mathrm{C}_{3} \mathrm{H}_{6} \mathrm{ON}_{2}^{+}\right), 97\left(\mathrm{C}_{4} \mathrm{H}_{5} \mathrm{ON}_{2}^{+}\right), 73\left(\mathrm{C}_{3} \mathrm{H}_{2} \mathrm{O}_{2} \mathrm{~N}^{+}\right), 86$ $\left(\mathrm{C}_{2} \mathrm{H}_{2} \mathrm{O}_{2} \mathrm{~N}_{2}^{+}\right)$and $91\left(\mathrm{C}_{3} \mathrm{H}_{9} \mathrm{O}_{2} \mathrm{~N}^{+}\right)$. Although the signal intensities of $\mathrm{N}$-containing fragments are weaker than those of the $\mathrm{C}_{x} \mathrm{H}_{y}, \mathrm{C}_{x} \mathrm{H}_{y} \mathrm{O}$ and $\mathrm{C}_{x} \mathrm{H}_{y} \mathrm{O}_{2}$ families, the results demonstrate that $\mathrm{N}$-containing species are formed. Our results are consistent with previous work that observed a significant increase in the fraction of organic constituents with one or two $\mathrm{N}$ atoms for $\mathrm{NH}_{3}$-aged $\alpha$-pinene SOA (Flores et al., 2014).

Similar OA mass spectra were obtained from the $\mathrm{OH}$ oxidation $\left(\mathrm{H}_{2} \mathrm{O}_{2}+h v\right)$ of $m$-xylene (Fig. S3). As shown in Fig. S3, the relative intensities of $\mathrm{C}_{x} \mathrm{H}_{y}, \mathrm{C}_{x} \mathrm{H}_{y} \mathrm{O}$ and $\mathrm{C}_{x} \mathrm{H}_{y} \mathrm{O}_{2}$ fragment families are slightly different than those of SOA formed via $\mathrm{OH}$ oxidation of $m$-xylene reported previously (Loza et al., 2012). This is likely due to differences in experimental conditions such as the oxidant level and mass loading. The mass spectrum of $\mathrm{N}$-containing fragments for $m$-xylene-derived SOA are given in Fig. S3b, and are also somewhat different than those observed for $\alpha$-pinenederived SOA (Fig. 1b). For example, the fragments at $m / z 68$ $\left(\mathrm{C}_{3} \mathrm{H}_{4} \mathrm{~N}_{2}^{+}, \mathrm{C}_{4} \mathrm{H}_{6} \mathrm{~N}^{+}\right.$and $\left.\mathrm{C}_{3} \mathrm{H}_{2} \mathrm{ON}^{+}\right), 91\left(\mathrm{C}_{3} \mathrm{H}_{9} \mathrm{O}_{2} \mathrm{~N}^{+}\right)$and
$97\left(\mathrm{C}_{4} \mathrm{H}_{5} \mathrm{ON}_{2}^{+}\right)$are significantly weaker in the SOA from $m$-xylene (Fig. S3b) than those from the ozonolysis of $\alpha$ pinene (Fig. 1b), suggesting the presence of different types and quantities of the SOA functional groups required for the organonitrogen forming heterogeneous reactions.

The formation of NOC is further confirmed via the IR spectra of the SOA formed in the presence of $\mathrm{NH}_{3}$. The IR spectra of SOA from the ozonolysis of $\alpha$-pinene and the $\mathrm{OH}$ oxidation of $m$-xylene is shown in Fig. 2 and the assignments of the observed IR bands are summarized in Table S1. After $6 \mathrm{~h}$ of ammonia exposure ,a number of nitrogen containing bands are tentatively identified. These include $\mathrm{NH}_{x}\left(v_{\mathrm{as}, \mathrm{NH} 2}: 3490 ; v_{\mathrm{as}, \mathrm{NH}_{4}^{+}}: 3240 \mathrm{~cm}^{-1} ; \delta_{\mathrm{NH}}\right.$ or $v_{s, \mathrm{CN}}$ 1563 ; and 785 or $\left.740 \mathrm{~cm}^{-1}\right)$ and $\mathrm{C}=\mathrm{N}\left(v_{s, \mathrm{CN}}: 1640 ; v_{s, \mathrm{CN}}\right.$ : $1660 \mathrm{~cm}^{-1}$ ) (Nguyen et al., 2013; Lin-Vien et al., 1991), functional groups which are observable in the SOA from both $\alpha$-pinene and $m$-xylene. The generally small IR signals associated with the NOC make it difficult to conclusively assign a number of potential NOC bands particularly since the expected dominant carbonyl and organic acid functional groups associated with SOA are also observed (Table S1).

While the above IR assignments are common between experiments using both VOC precursors, the $\mathrm{OH}$ oxidation of $m$-xylene resulted in a very strong band at $2195 \mathrm{~cm}^{-1}$, which was not present in the $\alpha$-pinene-derived SOA (Fig. 2)

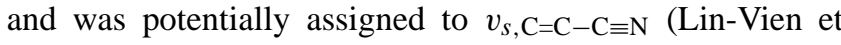
al., 1991) (a nitrile). At the present time, the exact formation mechanism leading to this functional group is unknown. However, the double bond adjacent to the nitrile group suggests that it is unique to the oxidative ring opening of $\mathrm{m}$ xylene (and likely other aromatics), which is not accessible in the $\alpha$-pinene system. Regardless, the functional groups revealed in the IR absorption spectra supports the HR-ToFAMS results and confirms the formation of particle-bound NOC.

\subsection{Potential mechanisms contributing to observed NOC}

Several mechanisms have been postulated previously with respect to NOC formation in the presence of ammonia (Zhang et al., 2015). The various mechanisms generally fall into two categories: reactions of ammonia/ammonium with carbonyl functional groups in SOA leading to the formation of species with covalently bonded carbon to nitrogen (X. F. Wang et al., 2010; Zarzana et al., 2012; Yu et al., 2011; Powelson et al., 2014; A. K. Y. Lee et al., 2013; Trainic et al., 2011; Zhang et al., 2015), or acid-base reactions between ammonia/ammonium and organic/inorganic acid species in particles leading to organic ammonium salts (Liu et al., 2012b; Kuwata and Martin, 2012; Zhang et al., 2015).

Several studies have identified the presence of NOC in laboratory generated SOA associated with the presence of carbonyl groups and $\mathrm{NH}_{4}^{+}$(the dominant form of $\mathrm{NH}_{3}$ in particles). For example, using an HR-ToF-AMS, N-containing 


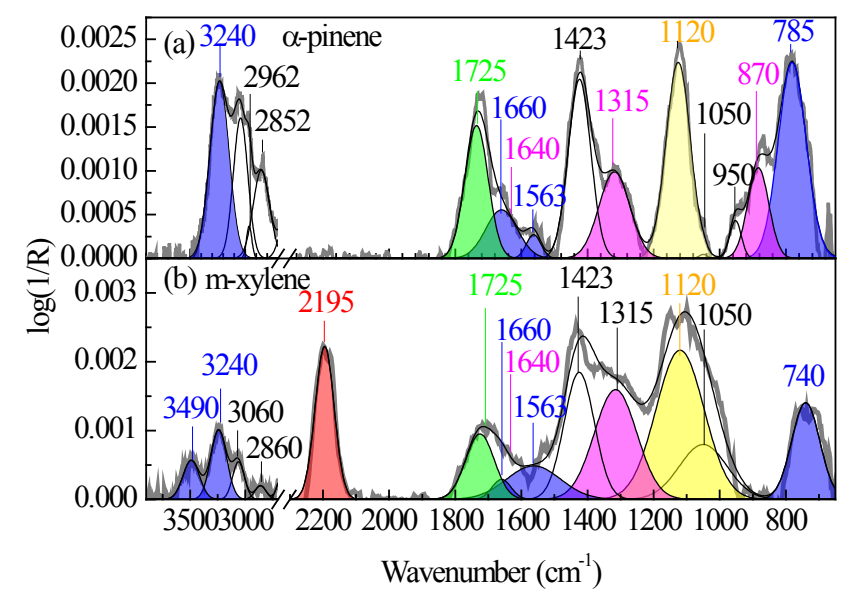

Figure 2. Infrared spectra for SOA from (a) ozonolysis of $\alpha$-pinene (Exp. P11) and (b) $\mathrm{OH}$ oxidation of $m$-xylene (Exp. M15) in the presence of $\mathrm{NH}_{3} . R$ is the abbreviation for reflectance in DRIFTS mode.

fragments including strong ions at $m / z 41,68,69$ and 70 and weak ions at $m / z 46,52,53,57,68$ and 96 have been identified for the uptake of glyoxal on ammonium sulfate particles (Galloway et al., 2009), attributed to imine and/or imidazole formation. Higher molecular weight $\mathrm{N}$-containing molecular ions such as $m / z 97\left(\mathrm{C}_{4} \mathrm{H}_{5} \mathrm{ON}_{2}^{+}\right), 115\left(\mathrm{C}_{4} \mathrm{H}_{7} \mathrm{O}_{2} \mathrm{~N}_{2}^{+}\right)$, $129\left(\mathrm{C}_{5} \mathrm{H}_{9} \mathrm{O}_{2} \mathrm{~N}_{2}^{+}\right), 159\left(\mathrm{C}_{6} \mathrm{H}_{11} \mathrm{O}_{3} \mathrm{~N}_{2}^{+}\right), 173\left(\mathrm{C}_{7} \mathrm{H}_{13} \mathrm{O}_{3} \mathrm{~N}_{2}^{+}\right)$, $184\left(\mathrm{C}_{7} \mathrm{H}_{10} \mathrm{O}_{3} \mathrm{~N}_{3}^{+}\right)$have also been detected using high resolution electrospray ionization mass spectrometry (ESI-MS) for the same reaction system (Galloway et al., 2009). In addition, SOA, which was formed through the ozonolysis of $\alpha$-pinene and $d$-limonene, subsequently impacted on a polymeric plate and then exposed to gaseous $\mathrm{NH}_{3}$, resulted in a significant enhancement in relative abundance of several NOC molecules, such as $\mathrm{C}_{9} \mathrm{H}_{11} \mathrm{NO}_{2}, \mathrm{C}_{9} \mathrm{H}_{13} \mathrm{NO}_{2}$, $\mathrm{C}_{19} \mathrm{H}_{29} \mathrm{NO}_{4}, \mathrm{C}_{19} \mathrm{CH}_{29} \mathrm{NO}_{5}$ and $\mathrm{C}_{19} \mathrm{H}_{33} \mathrm{NO}_{5}$ (Laskin et al., 2014).

Presently, the gas-phase oxidation mechanism of $\alpha$-pinene by ozone has been fairly well elucidated. In general, the initial step proceeds through cycloaddition of $\mathrm{O}_{3}$ to the $\mathrm{C}=\mathrm{C}$ bond, forming an excited primary ozonide ( $\mathrm{POZ}$ ). The POZ undergoes a unimolecular isomerization to produce Criegee intermediates (CIs), which subsequently yield both gas-phase and particle-phase compounds containing hydroxyl, carbonyl and acidic functional groups (Zhang and Zhang, 2005; Yu et al., 1999). In particular, previous work has found that organic acids are the dominant SOA component (Ma et al., 2013). The $\mathrm{OH}$ initialed oxidation mechanism of $m$-xylene is more complex as described by the Master Chemical Mechanism MCM3.1 (Bloss et al., 2005); however it also leads to particle-phase acids and carbonyls (Loza et al., 2012). It has been found that $\alpha$-dicarbonyls are likely the most dominant form of products from the $\mathrm{OH}$-initiated oxidation of $m$-xylene (Zhao et al., 2005).
Particle-phase carbonyl compounds are present in the current experiments as confirmed by IR absorption band at $1725 \mathrm{~cm}^{-1}$ (in both systems). The observed HR-ToF-AMS fragment families of $\mathrm{C}_{x} \mathrm{H}_{y} \mathrm{~N}_{n}, \mathrm{C}_{x} \mathrm{H}_{y} \mathrm{ON}_{n}$ and $\mathrm{C}_{x} \mathrm{H}_{y} \mathrm{O}_{2} \mathrm{~N}_{n}$ indicates that $\mathrm{C}-\mathrm{N}$ bonds have formed and they are qualitatively similar to those associated with imine and/or imidazole formation (Nguyen et al., 2013; A. K. Y. Lee et al., 2013) which is generally summarized in Scheme S1. The HR-ToFAMS fragments and the formation of imine bonds are also consistent with the IR-derived functional groups of $\mathrm{NH}_{x}$ and $\mathrm{C}=\mathrm{N}$ observed in this study (Fig. 2; Table S1).

Previous studies have observed the neutralization reaction between $\mathrm{NH}_{3}$ and organic acids in both flow reactor (Paciga et al., 2014) and environmental chambers (Na et al., 2007). In particular, high concentrations of $\mathrm{NH}_{3}$ greatly promoted SOA formation from ozonlysis of $\alpha$-pinene (Na et al., 2007). This was ascribed to the formation of organic ammonium salts. Therefore, the formation of organic ammonium salts in the current work cannot be entirely discounted. The $\mathrm{NH}_{x}$ bands in the IR (3490 and $3240 \mathrm{~cm}^{-1}$ ) as well as the $\mathrm{NH}_{x}$ fragments of the HR-ToF-AMS may arise from the ammonium ion associated with an organic ammonium salt. Although organic acids, whose IR absorbance bands appear at $3300-2500 \mathrm{~cm}^{-1}$ for $v_{s}(\mathrm{OH}), 1760-1690 \mathrm{~cm}^{-1}$ for $v_{s}(\mathrm{C}=\mathrm{O}), 1320-1210 \mathrm{~cm}^{-1}$ for $v_{s}(\mathrm{C}-\mathrm{O}), 1440-1395$ and $950-910 \mathrm{~cm}^{-1}$ for $\delta(\mathrm{OH})$ (Lin-Vien et al., 1991) were observed, it is likely that the majority of $\mathrm{NH}_{x}$ arose from the association with acidic sulfate which may need to be fully neutralized prior to the formation of organic salts. Regardless, organic salts which primarily contribute to the AMSderived $\mathrm{NH}_{x}$ fragments would not result in fragments containing $\mathrm{N}, \mathrm{C}$ and $\mathrm{O}$ (i.e., $\mathrm{C}_{x} \mathrm{H}_{y} \mathrm{~N}_{n}, \mathrm{C}_{x} \mathrm{H}_{y} \mathrm{ON}_{n}, \mathrm{C}_{x} \mathrm{H}_{y} \mathrm{O}_{2} \mathrm{~N}_{n}$ and $\mathrm{NO}_{x}$ ) which account for the majority of NOC fragments observed. Finally, the formation of organic ammonium salts is inconsistent with the observed acidity effect on the uptake coefficients leading to NOC (see Sect. 3.6).

The mechanisms described above intrinsically assume that heterogeneous reactions occur after the $\mathrm{NH}_{3}$ uptake onto the SOA. However, gas-phase reactions between $\mathrm{NH}_{3}$ and gaseous organic carbonyls and/or acids and subsequent condensation may in principle contribute to the observed particle-phase NOC. Reactions of $\mathrm{NH}_{3} / \mathrm{NH}_{4}^{+}$with carbonyls are generally acid catalyzed (Zhang et al., 2015), as shown in Scheme S1, for both the reaction to form Schiff base and Mannich reaction. This suggests that if the NOC were gas phase reaction products, a termolecular reaction would be necessary among carbonyls, acid and $\mathrm{NH}_{3}$ in the gas phase; the rates of which are exceedingly slow. Furthermore, gasphase reactions leading to particle phase NOC should be negligible since the calculated reactive uptake coefficients $(\gamma)$ of $\mathrm{NH}_{3}$ are positively correlated with particle-phase acidity, and anti-correlated with $\mathrm{NH}_{3}$ concentration as will be discussed in Sect. 3.6. An anti-correlation with the gaseous reactant is characteristic of heterogeneous reactions (Ma et al., 2010). 
Therefore, as pointed out in Sect. 2.2, the uptake coefficients derived including $\mathrm{NH}_{x}^{+}$should be an upper bound to $\gamma$.

\subsection{Contribution of inorganic and organic $\mathrm{NO}_{y}$ species to NOC}

In addition to $\mathrm{C}_{x} \mathrm{H}_{y} \mathrm{~N}_{n}, \mathrm{C}_{x} \mathrm{H}_{y} \mathrm{ON}_{n}$ and $\mathrm{C}_{x} \mathrm{H}_{y} \mathrm{O}_{2} \mathrm{~N}_{n}$ fragments as shown in Figs. 1 and $\mathrm{S} 3$, strong signals from $\mathrm{NO}_{x}$ $\left(\mathrm{NO}^{+} ; m / z \quad 30\right.$ and $\left.\mathrm{NO}_{2}^{+} ; m / z 46\right)$ are also observed in the particle mass spectra of both VOC systems. These $\mathrm{NO}_{x}$ fragments may have arisen from processes other than the uptake of $\mathrm{NH}_{3} . \mathrm{NO}_{x}$ fragments in the HR-ToF-AMS spectra can originate from particle-bound $\mathrm{NOC}$, inorganic $\mathrm{NO}_{y}\left(\mathrm{HNO}_{3}\right.$ or $\mathrm{NH}_{4} \mathrm{NO}_{3}$ ) and/or organic nitrates possibly formed via the chain termination of $\mathrm{RO}_{2}$ or $\mathrm{RO}$ radicals by the trace levels of $\mathrm{NO}$ or $\mathrm{NO}_{2}$ in the chamber. Although zero air was used in this study, trace levels of $\mathrm{NO}_{y}$ (oxides of nitrogen except $\mathrm{N}_{2} \mathrm{O}$ ) were detected in the chamber as shown in Fig. S4. The maximum $\mathrm{NO}_{y}$ concentration was approximately $0.25 \mathrm{ppbv}$, but generally much lower.

Figure S5 compares the concentrations of particle-phase $\mathrm{NO}_{x}\left(\mathrm{NO}^{+}+\mathrm{NO}_{2}^{+}\right)$and total $\mathrm{NOC}$ $\left(T_{\mathrm{NOC}}=\mathrm{C}_{x} \mathrm{H}_{y} \mathrm{~N}_{n}+\mathrm{C}_{x} \mathrm{H}_{y} \mathrm{ON}_{n}+\mathrm{C}_{x} \mathrm{H}_{y} \mathrm{O}_{2} \mathrm{~N}_{n}+\mathrm{NO}_{x}\right)$ in a typical SOA experiment with a control experiment performed in the absence of $\alpha$-pinene ( $0 \mathrm{ppbv}$ ). The $\mathrm{NO}_{x}$ and $T_{\text {NOC }}$ concentrations in the control experiment increased only slightly (from $5.4 \times 10^{-17}$ to $8.4 \times 10^{-17} \mathrm{~g} \mathrm{particle}^{-1}$ for $\left.T_{\text {NOC }}\right)$ compared to the increases observed in the presence of VOC (from $7.6 \times 10^{-17}$ to $2.9 \times 10^{-16} \mathrm{~g} \mathrm{particle}^{-1}$ for $\left.T_{\mathrm{NOC}}\right)$. Assuming that the increase in $T_{\mathrm{NOC}}$ in the control experiment was entirely from $\mathrm{NO}_{y}$, it would contribute a maximum of $14 \%$ of the $T_{\mathrm{NOC}}$ mass measured in the typical SOA experiment shown in Fig. S5. In the control experiment $\mathrm{NO}_{x}$ fragments accounted for $74.7 \pm 4.9 \%$ of $T_{\mathrm{NOC}}$; hence, the possible contribution of inorganic $\mathrm{NO}_{y}$ to $T_{\mathrm{NOC}}$ mass in a typical SOA experiment is likely even lower $(10.5 \pm 0.7) \%$. This estimation is considered an upper limit to the contributions from inorganic $\mathrm{NO}_{y}$ species, since $0.4 \mu \mathrm{g} \mathrm{m}^{-3}$ of SOA were formed in the control experiment after $6 \mathrm{~h}$ of reaction (possibly from the background air of the chamber), suggesting that a small amount of NOC in control experiments may also be formed via the uptake of $\mathrm{NH}_{3}$ by trace amounts of SOA, which could have contributed at least partially to the $\mathrm{NO}^{+}$and $\mathrm{NO}_{2}^{+}$ions in the particle mass spectrum in the control experiment. It should also be pointed out that the $\mathrm{OH}$ concentration in a typical oxidation experiment here is likely higher than that in the control experiment, potentially resulting in a higher level of inorganic $\mathrm{NO}_{y}$.

A further constraint on the contributions of inorganic $\mathrm{NO}_{y}$ to the HR-ToF-AMS fragments at $m / z 30$ and $m / z 46$ may be obtained by assuming that all of the measured gaseous $\mathrm{NO}_{y}$ is $\mathrm{HNO}_{3}$ (in a typical SOA experiment). Under this condition, the solvation of $\mathrm{HNO}_{3}$ into surface water would contribute to less than $4 \times 10^{-21} \mathrm{~g}_{\text {particle }}-1$ of $\mathrm{HNO}_{3}$, calculated using the reported growth factor (GF) of SOA from ozonolysis of $\alpha$-pinene ( 1.015 at $50 \% \mathrm{RH}$ for $180 \mathrm{~nm}$ particle) (Varutbangkul et al., 2006) and the Henry's law constant of $\mathrm{HNO}_{3}$ of $2.1 \mathrm{~mol} \mathrm{~kg}^{-1} \mathrm{~Pa}^{-1}$ at $298 \mathrm{~K}$ (Lelieveld and Crutzen, 1991). This value is significantly lower than the detected particle $\mathrm{NO}_{x}$ fragment mass concentration in the current experiments $\left(\sim 10^{-17} \mathrm{~g} \mathrm{particle}^{-1}\right)$ and suggests that the impact of $\mathrm{HNO}_{3}$ from the trace level $\mathrm{NO}_{x}$ in the gas phase during the experiments on the particle NOC is negligible. In addition, if both $\mathrm{NH}_{3}$ and $\mathrm{NO}_{x}$ (ultimately $\mathrm{HNO}_{3}$ ) are present in the reaction system, then $\mathrm{NH}_{4} \mathrm{NO}_{3}$ may be formed (and possibly dissociated into $\mathrm{NH}_{4}^{+}$and $\mathrm{NO}_{3}^{-}$). Aqueous $\mathrm{NH}_{4} \mathrm{NO}_{3}$ (i.e., $\mathrm{NH}_{4}^{+}$and $\mathrm{NO}_{3}^{-}$) can likely be excluded because the RH $(50 \%)$ in this study is lower than the deliquescence $\mathrm{RH}$ (DRH, 62\%) of $\mathrm{NH}_{4} \mathrm{NO}_{3}$ (Lightstone et al., 2000). Regardless, the characteristic IR bands of $\mathrm{NO}_{3}^{-}$at 1047,830 and $713 \mathrm{~cm}^{-1}$ (Wu et al., 2007), and the strong characteristic IR bands of $\mathrm{NH}_{4} \mathrm{NO}_{3}(\mathrm{~s})$ at 1340,1390 and $1630 \mathrm{~cm}^{-1}$ (Miller and Wilkins, 1952) were not observed in Fig. 2. These results imply that a possible interference by inorganic $\mathrm{NH}_{4} \mathrm{NO}_{3}$ at $m / z 30$ and 46 is not likely.

While inorganic $\mathrm{NO}_{y}\left(\mathrm{HNO}_{3} \& \mathrm{NH}_{4} \mathrm{NO}_{3}\right)$ had little influence on the observed particle $\mathrm{NO}^{+} / \mathrm{NO}_{2}^{+}$fragments (as described above), organic $\mathrm{NO}_{y}$ partitioning may also be possible, leading to NOC that was not derived via the uptake of $\mathrm{NH}_{3}$. In the presence of NO larger than 10-30 pptv, organonitrates $\left(\mathrm{RONO}_{2}\right)$ can be formed through reactions between organic peroxy radicals $\left(\mathrm{RO}_{2}\right)$ and NO (Arey et al., 2001). The initial NO concentration in these chamber experiments was $\sim 25 \mathrm{pptv}$ (Fig. S6). The limited resolution of the FTIR measurements makes it difficult to differentiate between $\mathrm{RONO}_{2}$ and other NOC bands $(\sim 1640,1315$, $870 \mathrm{~cm}^{-1}$; Fig. 2 and Table S1). However, a number of observations described below suggest that photo-chemically derived $\mathrm{RONO}_{2}$ (hence not NOC from $\mathrm{NH}_{3}$ ) was a minor contributor to the observed $\mathrm{NO}_{x}$ fragments, and a further negligible source of $\mathrm{C}_{x} \mathrm{H}_{y} \mathrm{ON}_{n}$ and $\mathrm{C}_{x} \mathrm{H}_{y} \mathrm{O}_{2} \mathrm{~N}_{n}$ fragments. Firstly, the photo-chemical formation of organonitrates in various VOC systems is usually associated with the formation of significantly more $\mathrm{HNO}_{3}\left(\mathrm{NH}_{4} \mathrm{NO}_{3}\right.$ in this study) which was not observed in the IR measurements here. Secondly, AMS measurements have demonstrated that the $\mathrm{NO}^{+} / \mathrm{NO}_{2}^{+}$ratio specifically for monoterpene-derived organonitrates is in the range of 10-15 (Bruns et al., 2010; Fry et al., 2009), in contrast to that of the current study $(\sim 2)$. Thirdly, Farmer et al. (Farmer et al., 2010) have shown that $\mathrm{C}_{x} \mathrm{H}_{y} \mathrm{ON}_{n}$ and $\mathrm{C}_{x} \mathrm{H}_{y} \mathrm{O}_{2} \mathrm{~N}_{n}$ fragments from organonitrate standards typically account for $<5 \%$ of the total $\mathrm{N}$ containing mass, in contrast to the current study where they account for $\sim 30 \%$ (Table 2). Finally, there was an observed positive correlation between particle-phase acidity and the derived uptake coefficients (described in Sect. 3.6) based upon these NOC fragments, which is inconsistent with $\mathrm{RONO}_{2}$ formed photo-chemically in the gas-phase. Consequently, $\mathrm{NO}_{x}, \mathrm{C}_{x} \mathrm{H}_{y} \mathrm{ON}_{n}$ and $\mathrm{C}_{x} \mathrm{H}_{y} \mathrm{O}_{2} \mathrm{~N}_{n}$ fragments are likely to have arisen primarily from the het- 


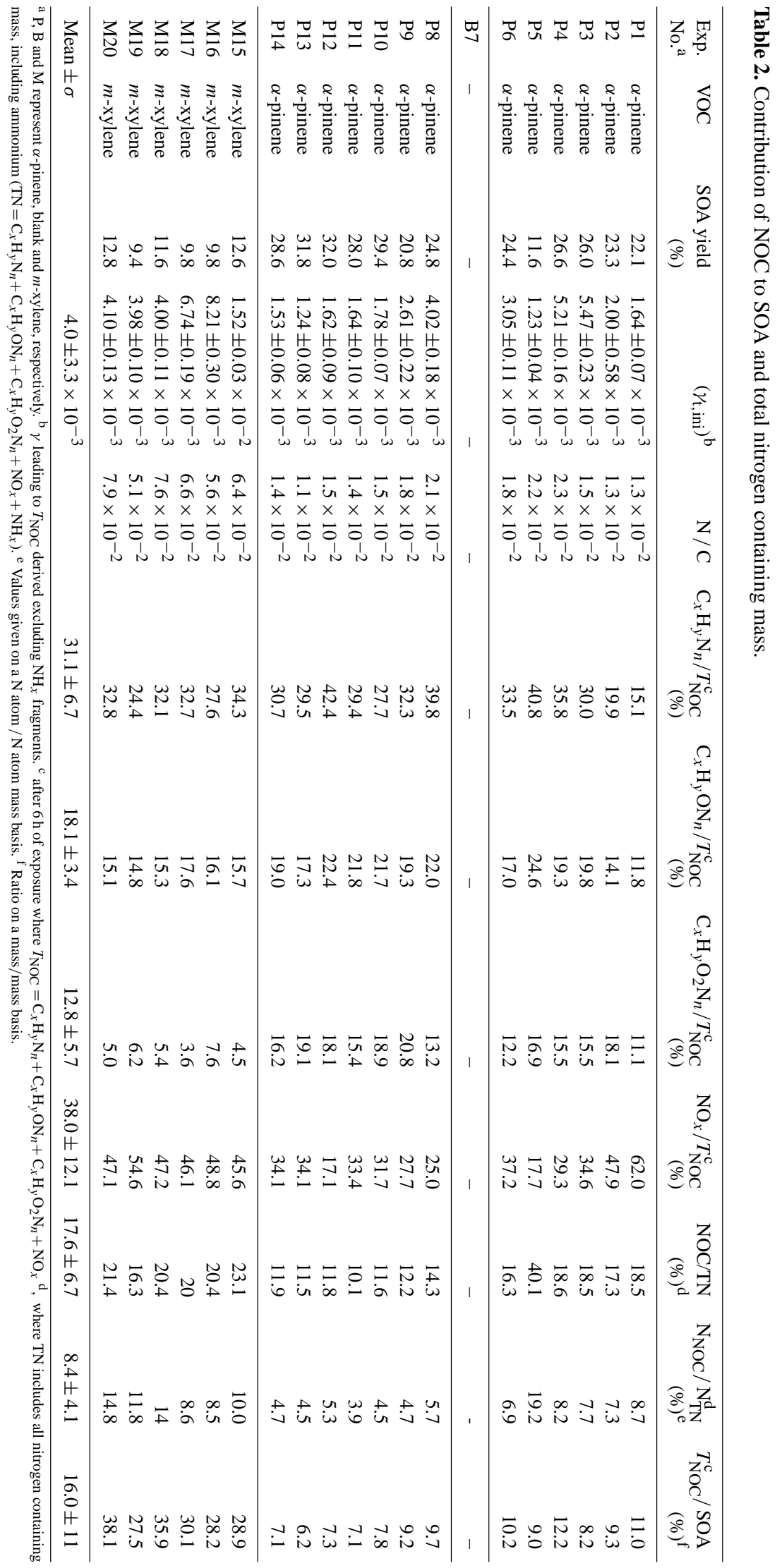


erogeneous reactions of $\mathrm{NH}_{3}$, and are thus included in subsequent kinetic calculations.

\subsection{Contribution of NOC to SOA}

The temporal evolution of the four families of N-containing fragments (excluding $\mathrm{NH}_{x}$ ) and the total SOA during ozonolysis of $\alpha$-pinene and $\mathrm{OH}$ oxidation of $m$-xylene are shown in Fig. 3a and b, respectively. Note that NOC as defined here is not likely to be a result of acid-base (organic acid- $\mathrm{NH}_{3}$ ) reactions since $\mathrm{NH}_{x}$ fragments are excluded (see Sect. 3.2). The relative contribution of $T_{\mathrm{NOC}}$ to SOA is shown in Fig. $3 \mathrm{c}$ and $\mathrm{d}$ and summarized for all experiments in Table 2. As shown in Fig. $3 \mathrm{a}$ and $\mathrm{b}$, once the ozonolysis or $\mathrm{OH}$ oxidation was initiated all $\mathrm{N}$-containing fragments increase significantly with time; but their growth rates were much smaller than that for the bulk of the SOA, as demonstrated by the relatively sharp decline in the $T_{\mathrm{NOC}} / \mathrm{SOA}$ of Fig. $3 \mathrm{c}$ and d. Nonetheless, after $6 \mathrm{~h}$ of exposure in these experiments, $\mathrm{N}$-containing species (based on the quantified HR-ToF-AMS fragments excluding $\mathrm{NH}_{x}$ ) contributed $8.9 \pm 1.7$ and $31.5 \pm 4.4 \mathrm{wt} \%$ (average over all experiments) of the total SOA mass from the ozonolysis of $\alpha$-pinene and $\mathrm{OH}$ oxidation of $m$-xylene, respectively. As discussed in Sect. 3.2, $\alpha$-dicarbonyls are likely the most dominant products from the $\mathrm{OH}$-initiated oxidation of $m$-xylene (Zhao et al., 2005), while organic acids are likely the dominant SOA components derived from ozonolysis of $\alpha$-pinene (Ma et al., 2013). This is consistent with the higher NOC content in the total SOA mass from the $\mathrm{OH}$ oxidation of $m$-xylene as shown in Fig. 3. After $6 \mathrm{~h}$ of reaction, as summarized in Table 2, the mean $\mathrm{N} / \mathrm{C}$ ratio is $0.016 \pm 0.004$ for the ozonolysis of $\alpha$-pinene and $0.065 \pm 0.011$ for the $\mathrm{OH}$ oxidation of $m$-xylene. These $\mathrm{N} / \mathrm{C}$ ratios are comparable with that of low-volatility oxidized organic aerosol (OOA, 0.011) and a recently isolated nitrogen-enriched OA (0.053) (Sun et al., 2011). In a study of the ozonolysis of $d$-limonene by Laskin et al. (2010), it was found that $<6 \%$ of the extracted species from fresh SOA contained an $\mathrm{N}$ atom, which was ascribed to reactions with trace amounts of $\mathrm{NH}_{3}$ in the laboratory air or from reactions of dissolved analyte molecules with solvent (acetonitrile). This value $(6 \%)$ is comparable with the $T_{\text {NOC }}$ content of SOA from the ozonolysis of $\alpha$-pinene in this study (Table 1). In the reactions between glyoxal and ammonium, N-containing fragments contributed approximately $1 \%$ to the total SOA mass (Chhabra et al., 2010). The diversity in NOC mass fraction or N / C reported previously suggests that the $\mathrm{N}$-containing content of SOA will depend upon the conditions associated with the reaction system, such as the VOC, the oxidant, $\mathrm{NH}_{3}$ concentration, mass loading of SOA and the seed particle composition. Regardless, the relatively large contribution of $T_{\mathrm{NOC}}$ to the formed SOA here suggests that exposure of SOA in the atmosphere to ammonia may be an important mechanism leading to ambient particle phase nitrogen even in the absence of acidic particles (i.e., exp P5 here). Note that the above fractional NOC values are

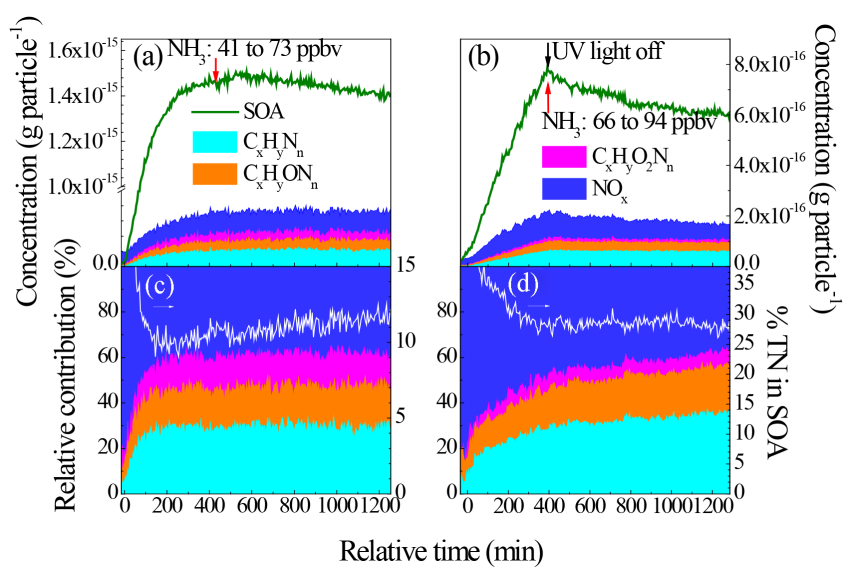

Figure 3. Concentration changes for $\mathrm{N}$-containing fragments and SOA for (a) ozonolysis of $\alpha$-pinene (Exp. P6) and (b) $\mathrm{OH}$ oxidation of $m$-xylene (Exp. M16), respectively; the relative fraction of each species to total NOC mass $\left(T_{\mathrm{NOC}}=\mathrm{C}_{x} \mathrm{H}_{y} \mathrm{~N}+\mathrm{C}_{x} \mathrm{H}_{y} \mathrm{ON}+\mathrm{C}_{x} \mathrm{H}_{y} \mathrm{O}_{2} \mathrm{~N}+\mathrm{NO}_{x}\right)$ and $T_{\mathrm{NOC}}$ to SOA fraction for (c) ozonolysis of $\alpha$-pinene and (d) $\mathrm{OH}$ oxidation of $m$-xylene, respectively.

probably underestimates, as a fraction of the measured $\mathrm{NH}_{x}$ will also arise from NOC, but is not included in the $T_{\text {NOC }}$ since the contribution of inorganic ammonium cannot be differentiated.

\subsection{Contribution of NOC to total nitrogen containing mass}

The relative contribution of each NOC fragment family to the $T_{\mathrm{NOC}}\left(T_{\mathrm{NOC}}=\mathrm{NO}_{x}+\mathrm{C}_{x} \mathrm{H}_{y} \mathrm{~N}_{n}+\mathrm{C}_{x} \mathrm{H}_{y} \mathrm{ON}_{n}+\mathrm{C}_{x} \mathrm{H}_{y} \mathrm{O}_{2} \mathrm{~N}_{n}\right)$, is also shown in Fig. $3 \mathrm{c}$ and $\mathrm{d}$. The above fragment contribution to $T_{\mathrm{NOC}}$, together with the ratio of $T_{\mathrm{NOC}}$ to the total nitrogen containing mass $\left(\mathrm{TN}=T_{\mathrm{NOC}}+\mathrm{NH}_{x}\right)$ and the $T_{\mathrm{NOC}} / \mathrm{TN}$ ratio on a nitrogen atom mass basis $\left(\mathrm{N}_{\mathrm{NOC}} / \mathrm{N}_{\mathrm{TN}}\right)$ are summarized for all experiments in Table 2. After $6 \mathrm{~h}$ of $\mathrm{NH}_{3}$ exposure (Fig. 3c), the ratio of $\mathrm{NO}_{x}, \mathrm{C}_{x} \mathrm{H}_{y} \mathrm{~N}_{n}$, $\mathrm{C}_{x} \mathrm{H}_{y} \mathrm{ON}_{n}$ and $\mathrm{C}_{x} \mathrm{H}_{y} \mathrm{O}_{2} \mathrm{~N}_{n}$ fragment families to $T_{\mathrm{NOC}}$ were $37.2,33.5,17.0$ and $12.2 \mathrm{wt} \%$, respectively for the ozonolysis of $\alpha$-pinene, and 45.6, 34.3, 15.7 and $4.5 \mathrm{wt} \%$ for the $\mathrm{OH}$ oxidation of $m$-xylene (Fig. $3 \mathrm{~d}$ ). These relative contributions to $T_{\mathrm{NOC}}$ were consistent between experiments and VOC systems, with the exception of $\mathrm{C}_{x} \mathrm{H}_{y} \mathrm{O}_{2} \mathrm{~N}_{n}$ fragments which contributed approximately 3 times less to the $T_{\mathrm{NOC}}$ in $m$-xylene experiments compared to those of $\alpha$-pinene (Table 2). Placed in the context of the total nitrogen containing mass (TN), which includes the inorganic ammonium, NOC formed from exposure of SOA to $\mathrm{NH}_{3}$ accounted for a substantial fraction of the TN $(\sim 10-20 \mathrm{wt} \%)$ with a generally greater contribution in the $m$-xylene system under otherwise similar conditions. However, a better indication of the importance of NOC forming reactions is derived by computing the above ratio on an atomic nitrogen mass basis $\left(\mathrm{N}_{\mathrm{NOC}} / \mathrm{N}_{\mathrm{TN}}\right.$; 
Table 2). Despite the carbon, hydrogen and oxygen content of the NOC fragments, the amount of N associated with NOC remains a significant contributor to the total $\mathrm{N}$ mass $(\sim 4-$ $15 \mathrm{wt} \%$ ), and is likely underestimated since an unknown fraction of $\mathrm{NH}_{x}$ will be from NOC. Such a high $\mathrm{N}$ content in these particles may have implications for ambient particulate nitrogen loading and subsequent $\mathrm{N}$ deposition which will be discussed further in Sect. 4.

\subsection{Reaction kinetics}

Typical temporal profiles for $T_{\mathrm{NOC}}$ during the ozonolysis of $\alpha$-pinene, which are used in the kinetic calculations, can be represented by those for Exp. P3 and P5 (Fig. 4). The open circles and solid triangles represent the experimental data, with the fit of the uptake model shown as red and blue lines during the initial (from 0 to $150 \mathrm{~min}$ ) and the final stages (from 400 to $1250 \mathrm{~min}$ ) of the experiment respectively. In these specific experiments (P3, P5), the observed initial reactive uptake coefficients of $\mathrm{NH}_{3}\left(\gamma_{\mathrm{obs} \text {, ini }}\right.$; on an atomic $\mathrm{N}$ mass basis) to form the $\mathrm{N}$ in NOC were $4.8 \pm 0.2 \times 10^{-3}$ and $1.07 \pm 0.03 \times 10^{-3}$, respectively. The true uptake coefficients $\left(\gamma_{\mathrm{t}, \mathrm{ini}}\right)$ were obtained by performing gas-phase diffusion corrections for $\mathrm{NH}_{3}$ using a previously reported empirical formula (Fuchs and Sutugin, 1970; Worsnop et al., 2002; Widmann and Davis, 1997) and the diffusion coefficient of $\mathrm{NH}_{3}$ in air $\left(0.1978 \mathrm{~cm}^{2} \mathrm{~s}^{-1}\right)$ (Massman, 1998). The corresponding $\gamma_{\mathrm{t} \text {,ini }}$ values for all experiments ranged from $1.23 \pm 0.04 \times 10^{-3}$ to $1.52 \pm 0.03 \times 10^{-2}$ (Table 2). As discussed above, a fraction of the observed $\mathrm{NH}_{x}$ fragments are likely to have arisen from NOC. However they are not included in the uptake coefficient estimates of Table 2 and thus result in an underestimate of $\gamma$. Conversely, including $\mathrm{NH}_{x}$ in the calculation of $\gamma$ (Table S2) is considered an overestimate. Despite this uncertainty, these uptake coefficients on the order of $10^{-3}$ are relatively large. At the present time, no data are available for comparison since the uptake kinetics of $\mathrm{NH}_{3}$ on organic aerosol has not been reported. However, the uptake coefficients measured in this study are similar to those observed for glyoxal (Liggio et al., 2005a, b; Liggio and Li, 2006a), and are 2-4 orders of magnitude higher than biogenic olefins (Liggio and Li, 2008) and pinonaldehyde (Liggio and $\mathrm{Li}, 2006 \mathrm{a})$ on acidic surfaces.

While not included in the derivation of $\gamma$ leading to NOC, the $\mathrm{NH}_{x}$ data from these experiments can be used to derive $\mathrm{NH}_{3}$ uptake coefficients leading to inorganic ammo$\operatorname{nium}\left(\gamma_{\mathrm{NH}_{4}^{+}}\right)$using the same approach as above. The resultant $\gamma_{\mathrm{NH}_{4}^{+}}$values are given in Table S2 and range from $5.3 \times 10^{-4}$ to $1.78 \times 10^{-2}\left(\right.$ mean $\left.=6.4 \times 10^{-3}\right)$ comparable to the range of $4 \times 10^{-3}-2 \times 10^{-4}$ reported for the competing uptake of $\mathrm{NH}_{3}$ with ambient organic gases by sulfuric acid (Liggio et al., 2011). The current uptake coefficients leading to $\mathrm{NH}_{4}^{+}$ are similar in magnitude to those leading to NOC, and significantly less than what would be expected based upon the

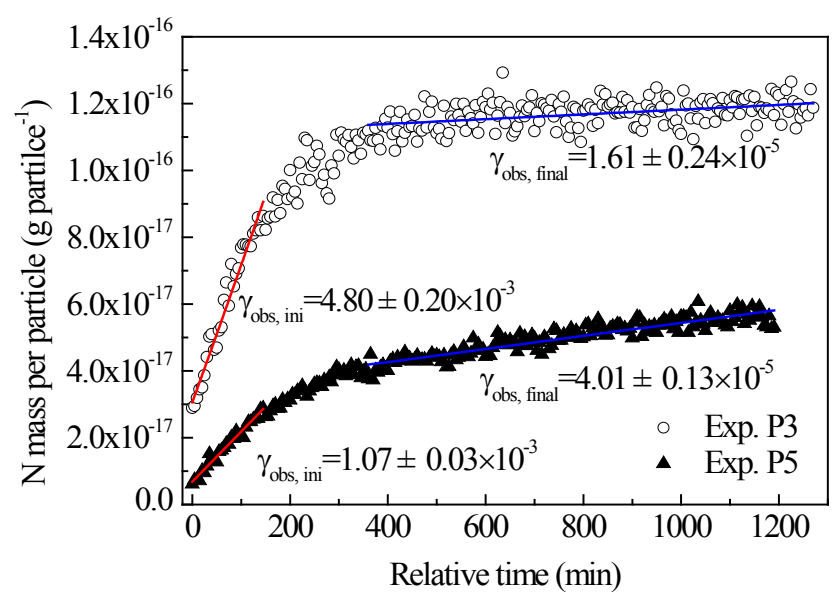

Figure 4. Fitting of mass changes (Exp. P3 and P5) to derive uptake coefficients for $\mathrm{NH}_{3}$ leading to $T_{\mathrm{NOC}}$. The red and blue lines represent the predicted values by the uptake model at the initial (from 0 to $150 \mathrm{~min}$ ) and the final stages of the experiment (from 400 to $1250 \mathrm{~min})$, respectively.

neutralization of sulfuric acid particle $(\sim 0.5-1$; Swartz et al., 1999). These results suggest that under these conditions, the formation of NOC can compete with the neutralization of acidic particles, possibly due to kinetic limitations on the uptake of $\mathrm{NH}_{3}$ caused by the coating of SOA as has been demonstrated previously (Liggio et al., 2011).

\subsection{Factors affecting reaction kinetics}

To determine the uptake kinetics of $\mathrm{NH}_{3}$ by relatively aged SOA during ozonolysis of $\alpha$-pinene or OH oxidation of $m$ xylene additional ammonia $(\Delta c: \sim 30 \mathrm{ppbv})$ was introduced into the reaction chamber after approximately $6 \mathrm{~h}$ of the original exposure. As shown in Fig. 3a and b, the additional $\mathrm{NH}_{3}$ did not result in a change in the absolute concentration of $\mathrm{N}$-containing species in the SOA. The ratio of TN to SOA increased slightly in the last half of the experiments, possibly due to the evaporation of SOA when $\alpha$-pinene was entirely consumed or further particle-phase oxidation by oxidants $\left(\mathrm{OH}\right.$ and/or $\left.\mathrm{O}_{3}\right)$. A reduced uptake of $\mathrm{NH}_{3}$ for the more aged SOA is also reflected in the derived uptake coefficients from the latter stages of the experiments. After $400 \mathrm{~min}$ of reaction (Fig. 4), the NOC uptake had slowed significantly, and the derived uptake coefficients of $\mathrm{NH}_{3}$ to form NOC decreased to $1.61 \pm 0.24 \times 10^{-5}$ and $4.01 \pm 0.13 \times 10^{-5}$, respectively.

A number of factors may explain the reduced uptake onto the more aged particles of these experiments (>400 min; Fig. 4). Firstly, this may suggest that in the latter stages of photochemistry, multi-generational particle-phase products of VOC oxidation contain functional groups not involved in the NOC forming heterogeneous reactions. However, the change in the $\mathrm{O} / \mathrm{C}$ ratio during these experiments was quite small; increasing to 0.46 from 0.4 over $6 \mathrm{~h}$ (Fig. S7). At the 
same time, precursor VOCs were not fully depleted after $6 \mathrm{~h}$, suggesting that carbonyls should continue to be formed throughout the experiment and not be entirely consumed via a heterogeneous reaction with $\mathrm{NH}_{3}$. Given that the postulated heterogeneous reactions (Mannich reaction and/or reaction to form Schiff base) are known to be acid catalyzed (Mitsumori et al., 2006), we suggest that a diffusion limitation to the acidic core of the particle (or to a region where acidity and carbonyls are unavailable) may be responsible for the slow decrease in uptake with time as significant amount of organic material (e.g., in the form of SOA) is added to the seed particles. This would have the effect of reducing the uptake of $\mathrm{NH}_{3}$ leading to both $\mathrm{NOC}$ and $\mathrm{NH}_{4}^{+}$, consistent with the derived $\gamma$ of both. In particular, the formation of oligomers of high molecular weight (which may be more likely to hinder liquid phase diffusion) has been noted to occur in various SOA systems (Kalberer et al., 2004; Gross et al., 2006). This is also consistent with previous laboratory studies in which a high $\mathrm{NH}_{3}$ exposure for several days is required to detect the BrC in SOA (Nguyen et al., 2013; H. J. Lee et al., 2013; Updyke et al., 2012). The current results suggest that the formation of NOC from $\mathrm{NH}_{3}$ uptake will be more efficient for newly formed SOA (which is accelerated in the presence of sulfuric acid) compared to aged SOA.

The relationship between $\gamma_{\mathrm{t} \text {,ini }}$ and the particle-phase acidity for the ozonolysis of $\alpha$-pinene is shown in Fig. 5. Since the $\mathrm{RH}(50 \pm 2 \%)$ was lower than the deliquescence $\mathrm{RH}$ (DRH) of the mixtures of $\mathrm{H}_{2} \mathrm{SO}_{4}-\mathrm{Na}_{2} \mathrm{SO}_{4}$ used $(\sim 80 \%)$, we cannot reasonably estimate the surface $\mathrm{pH}$ with the EAIM model (Friese and Ebel, 2010), though it is expected that some surface coverage of water exists. Alternatively, the mole ratio of $\mathrm{H}_{2} \mathrm{SO}_{4}$ to $\mathrm{Na}_{2} \mathrm{SO}_{4}$ is used as a qualitative metric for the acidity in Fig. 5. Namely, a higher ratio of $\mathrm{H}_{2} \mathrm{SO}_{4} / \mathrm{Na}_{2} \mathrm{SO}_{4}$ indicates stronger acidity. As shown in Fig. 5, the reactive uptake coefficient for the $T_{\mathrm{NOC}}\left(\gamma_{\mathrm{t}, \mathrm{ini}}\right)$ increased by approximately a factor of 4 with increasing particle-phase acidity. This is consistent with the previously postulated acid-catalyzed reaction mechanisms between carbonyls and $\mathrm{NH}_{3}$ or $\mathrm{NH}_{4}^{+}$(in equilibrium with gas phase $\mathrm{NH}_{3}$ ) in Scheme S1 and elsewhere (Nguyen et al., 2013; Bones et al., 2010). In Fig. 5, an upper and lower limit to this qualitative relationship with acidity is estimated by including and excluding $\mathrm{NH}_{x}$ in the derivation of $\gamma_{\text {t,ini, }}$, both of which bear the same relationship.

Further insight into the controlling factors in this system is also gained from the relationship between $\gamma_{\text {t,ini }}$ and gaseous $\mathrm{NH}_{3}$, which is shown in Fig. 6, for a fixed content of particle-phase sulfuric acid $\left(\mathrm{H}_{2} \mathrm{SO}_{4} / \mathrm{Na}_{2} \mathrm{SO}_{4}\right.$ in

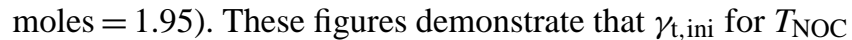
decreases with increases in $\mathrm{NH}_{3}(\mathrm{~g})$ concentration (regardless of the inclusion of $\mathrm{NH}_{x}$ into $\gamma$ ). In other reaction systems, an anti-correlation between uptake coefficients and gaseous reactant has been used to indicate that heterogeneous reactions occur on the particle surface, limited by an increasing number of ineffective collisions between the reactive sites and

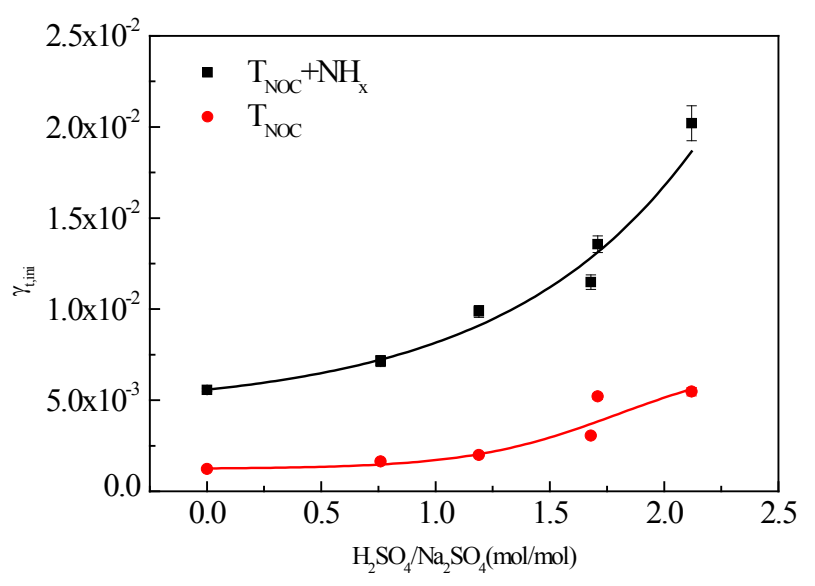

Figure 5. Relationship between the $\gamma_{\mathrm{t}, \text { ini }}$ and particle-phase acidity when including (black) and excluding (red) $\mathrm{NH}_{x}$ in the determination of $\gamma$. The error bars are derived from the uncertainties of the uptake model parameters.

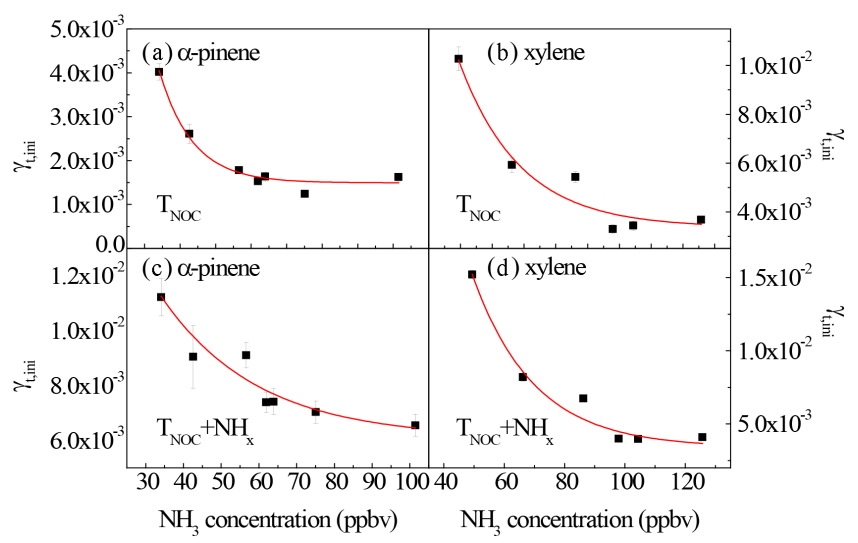

Figure 6. Diffusion corrected uptake coefficient of $\mathrm{NH}_{3}$ to form NOC species on SOA from $\mathrm{O}_{3}$ oxidation of $\alpha$-pinene (a) and $\mathrm{OH}$ oxidation of $m$-xylene (b), as a function of $\mathrm{NH}_{3}$ exposure (at fixed $\mathrm{H}_{2} \mathrm{SO}_{4} / \mathrm{Na}_{2} \mathrm{SO}_{4}$ ratio; $1.95 \mathrm{~mol} \mathrm{~mol}^{-1}$ ). This relationship is also shown for uptake coefficients derived including the $\mathrm{NH}_{x}$ fragments (c, d). The error bars depict $1 \sigma$.

the gaseous reactant (i.e., surface saturation; Ma et al., 2010; Pöschl et al., 2001; Mmereki and Donaldson, 2003; Kwamena et al., 2004). While this possibility cannot be ruled out here, the above acidity dependence argues against surface reaction, since a hydrophilic acidic seed is unlikely to be miscible with a somewhat hydrophobic SOA and thus migrate to the surface. Rather, we hypothesize that the relationship in Fig. 6 is driven by the kinetics of organic $+\mathrm{NH}_{3} / \mathrm{NH}_{4}^{+}$reactions that lead to the NOC. In this scenario, a larger $\gamma_{\text {t,ini }}$ would be observed at lower $\mathrm{NH}_{3}$ concentration when $\mathrm{NH}_{3}$ and/or $\mathrm{NH}_{4}^{+}$in the particle is rate limiting, and a reduced $\gamma_{\mathrm{t} \text {,ini }}$ at higher $\mathrm{NH}_{3}$ (Fig. 6) observed when the organic reactant is the rate limiting reagent in the formation of NOC. This argument is also consistent with a decrease in the $T_{\mathrm{NOC}}$ 
fraction of SOA with increasing SOA mass added as shown in Fig. 7, and again suggests that a barrier/diffusion limitation caused by organic coatings limits the formation of NOC in these experiments. The relatively few data points of Fig. 7 underlie the need for further systematic study to conclusively determine the controlling factors leading to the formation of NOC.

\section{Implications}

Organonitrogen compounds have been regarded as an important class of brown carbon in atmospheric particles, and may also have an influence on regional and global $\mathrm{N}$ deposition. As shown in this work, NOC compounds can be formed efficiently and quickly via the uptake of $\mathrm{NH}_{3}$ by newly formed SOA, in contrast to other studies where NOC forms over several days (Bones et al., 2010). If it is assumed that a steady state between NOC and SOA is established as observed in this study (i.e., Figs. 3 and 4), then a crude estimate of the formation rate of ambient $\mathrm{NOC}$ via the uptake of $\mathrm{NH}_{3}$ to biogenic SOA (BSOA) and anthropogenic SOA (ASOA) can be derived. Top-down estimates of global biogenic BSOA and anthropogenic ASOA formation have been estimated at approximately 88 and $10 \mathrm{Tg} \mathrm{Cyr}^{-1}$, respectively (Hallquist et al., 2009; Farina et al., 2010). Based upon the measured ratio of NOC in SOA (i.e., $(8.8 \pm 1.7) \mathrm{wt} \%$ for ozonolysis of $\alpha$ pinene and $(31.5 \pm 4.4) \mathrm{wt} \%$ for $\mathrm{OH}$ oxidation of $m$-xylene after $6 \mathrm{~h}$ ) and a value of 1.4 for OM / OC (Hallquist et al., 2009) the estimated global NOC via the reactive uptake of $\mathrm{NH}_{3}$ are then $10.8 \pm 2.1$ and $4.4 \pm 0.6 \mathrm{Tg} \mathrm{yr}^{-1}$ from BSOA and ASOA respectively, given sufficient $\mathrm{NH}_{3}$ availability. However, it should be noted that the lowest $\mathrm{NH}_{3}$ concentration used in this study was significantly higher than that typically found in the troposphere. While the dependence of the $\mathrm{NOC} / \mathrm{SOA}$ on $\mathrm{NH}_{3}$ concentration was weak in this high concentration regime, it is not clear if it remains so at more relevant $\mathrm{NH}_{3}$ levels. In addition, the formation of NOC may not reach a steady state in the atmosphere, as $\mathrm{NH}_{3}, \mathrm{SOA}$ and acidic sulfate can be present simultaneously, preventing the formation of an organic barrier as hypothesized in this study. The MAC of both BSOA and ASOA is known to be enhanced by $\mathrm{NH}_{3}$ aging (Updyke et al., 2012) however only to a maximum of $\sim 0.1 \mathrm{~m}^{2} \mathrm{~g}^{-1}$ at $500 \mathrm{~nm}$ wavelength. When compared to black carbon, with a MAC of $>10 \mathrm{~m}^{2} \mathrm{~g}^{-1}$ (Andreae and Gelencsér, 2006) and a global emission of $\sim 8 \mathrm{Tg} \mathrm{yr}^{-1}$ (Bond et al., 2004), the contribution of NOC originating from the uptake of $\mathrm{NH}_{3}$ by SOA to light absorption and the overall energy budget is likely to be small. It should be noted that light absorption by NOC may be relatively more important in the UV range, where NOC should have a much higher MAC. While this may not change the energy budget as significantly as black carbon, the actinic flux could be significantly changed, with different consequences. However, light

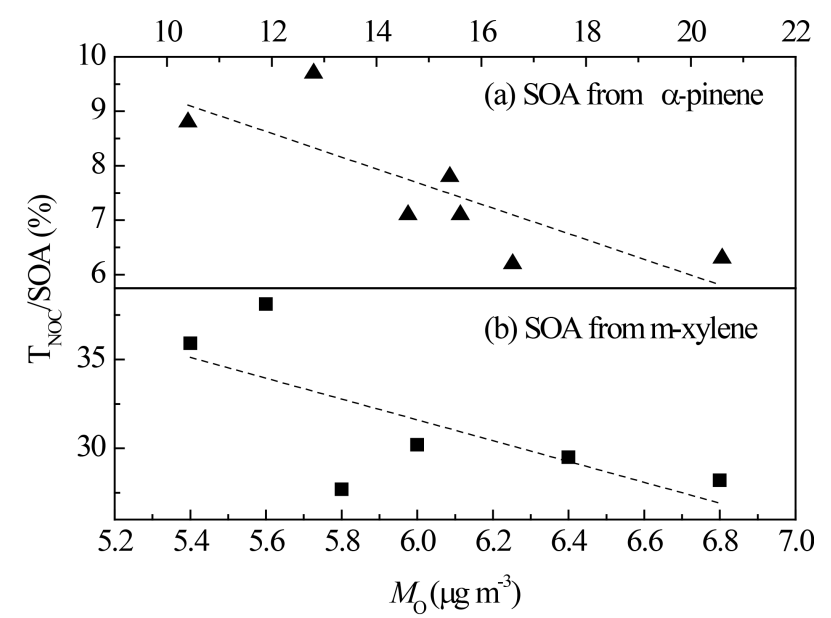

Figure 7. Relative contribution of NOC to the total SOA ( $\left.T_{\mathrm{NOC}} / \mathrm{SOA}\right)$ as a function of organic mass loading for $\alpha$ pinene and $m$-xylene experiments at constant particle acidity $\left(\mathrm{H}_{2} \mathrm{SO}_{4} / \mathrm{Na}_{2} \mathrm{SO}_{4}: 1.95\right)$.

absorption by NOC in atmospheric particles may be important regionally where the $\mathrm{BC}$ contribution is minimal.

Based upon the mean $\mathrm{N} / \mathrm{C}$ in SOA after $6 \mathrm{~h}$ of reaction $\left(1.6 \pm 0.4 \times 10^{-2} ; \alpha\right.$-pinene and $6.5 \pm 1.1 \times 10^{-2} ; m$-xylene $)$, the uptake of $\mathrm{NH}_{3}$ by BSOA and ASOA may contribute up to $1.4 \pm 0.4$ and $0.7 \pm 0.1 \mathrm{Tg} \mathrm{N} \mathrm{yr}^{-1}$ from the reactive uptake of $\mathrm{NH}_{3}$. Although these values are significantly less than the total global emission of $\mathrm{NH}_{3}\left(33.4 \mathrm{Tg} \mathrm{N} \mathrm{yr}^{-1}\right)$ (Reis et al., 2009), it may be important on a local or regional scale. The similarity between the uptake coefficients for NOC and inorganic $\mathrm{NH}_{4}^{+}$suggests that in the presence of organic coatings, NOC formation can compete with particle neutralization. Furthermore, under the conditions of these experiments up to $15 \%$ of the total $\mathrm{N}$ mass is attributed to NOC. If this value holds true for the ambient atmosphere, then a significant portion of $\mathrm{N}$ in PM is miss-represented as $\mathrm{NH}_{4}^{+}$or entirely unaccounted for. This will provide a means to transport more $\mathrm{N}$ further from ammonia sources and result in $\mathrm{N}$ deposition patterns poorly predicted by regional models (Cornell et al., 2003; Cape et al., 2011). Although a more thorough modeling study and further insight into the rates and mechanisms of NOC formation is required to clearly elucidate its impact on climate and regional nitrogen deposition, the results of this study suggest that $\mathrm{NOC}$ from $\mathrm{NH}_{3}$ should be considered with respect to overall deposition of $\mathrm{N}$ to sensitive ecosystems.

The Supplement related to this article is available online at doi:10.5194/acp-15-13569-2015-supplement. 
Acknowledgements. This research was financially supported by the Clean Air Regulatory Agenda (CARA), the National Natural Science Foundation of China (41275131) and the Strategic Priority Research Program of Chinese Academy of Sciences (XDB05040100).

Edited by: F. Keutsch

\section{References}

Aiken, A. C., Peter F. DeCarlo, and Jimenez, J. L.: Elemental analysis of organic species with electron ionization highresolution mass spectrometry, Anal. Chem., 79, 8350-8358, doi:10.1021/ac071150w, 2007.

Alexander, D. T. L., Crozier, P. A., and Anderson, J. R.: Brown carbon spheres in East Asian outflow and their optical properties, Science, 321, 833-836, doi:10.1126/science.1155296, 2008.

Andrade-Eiroa, A., Leroy, V., Dagaut, P., and Bedjanian, Y.: Determination of polycyclic aromatic hydrocarbons in kerosene and bio-kerosene soot, Chemosphere, 78, 1342-1349, doi:10.1016/j.chemosphere.2010.01.005, 2010.

Andreae, M. O. and Gelencsér, A.: Black carbon or brown carbon? The nature of light-absorbing carbonaceous aerosols, Atmos. Chem. Phys., 6, 3131-3148, doi:10.5194/acp-6-3131-2006, 2006.

Arey, J., Aschmann, S. M., Kwok, E. S. C., and Atkinson, R.: Alkyl nitrate, hydroxyalkyl nitrate, and hydroxycarbonyl formation from the nox-air photooxidations of $\mathrm{C}_{5}-\mathrm{C}_{8}$ n-alkanes, $\mathrm{J}$. Phys. Chem. A., 105, 1020-1027, doi:10.1021/jp003292z, 2001.

Beddows, D. C. S., Donovan, R. J., Harrison, R. M., Heal, M. R., Kinnersley, R. P., King, M. D., Nicholson, D. H., and Thompson, K. C.: Correlations in the chemical composition of rural background atmospheric aerosol in the UK determined in real time using time-of-flight mass spectrometry J. Environ. Monit., 6, 124-133, doi:10.1039/b311209h, 2004.

Bloss, C., Wagner, V., Jenkin, M. E., Volkamer, R., Bloss, W. J., Lee, J. D., Heard, D. E., Wirtz, K., Martin-Reviejo, M., Rea, G., Wenger, J. C., and Pilling, M. J.: Development of a detailed chemical mechanism (MCMv3.1) for the atmospheric oxidation of aromatic hydrocarbons, Atmos. Chem. Phys., 5, 641-664, doi:10.5194/acp-5-641-2005, 2005.

Bond, T. C., Streets, D. G., Yarber, K. F., Nelson, S. M., Woo, J.-H., and Klimont, Z.: A technology-based global inventory of black and organic carbon emissions from combustion, J. Geophys. Res., 109, D14203, doi:10.1029/2003JD003697, 2004.

Bond, T. C., Doherty, S. J., Fahey, D. W., Forster, P. M., Berntsen, T., DeAngelo, B. J., Flanner, M. G., Ghan, S., Kärcher, B., Koch, D., Kinne, S., Kondo, Y., Quinn, P. K., Sarofim, M. C., Schultz, M. G., Schulz, M., Venkataraman, C., Zhang, H., Zhang, S., Bellouin, N., Guttikunda, S. K., Hopke, P. K., Jacobson, M. Z., Kaiser, J. W., Klimont, Z., Lohmann, U., Schwarz, J. P., Shindell, D., Storelvmo, T., Warren, S. G., and Zender, C. S.: Bounding the role of black carbon in the climate system: A scientific assessment, J. Geophys. Res.-Atmos., 118, 5380-5552, doi:10.1002/jgrd.50171, 2013.

Bones, D. L., Henricksen, D. K., Mang, S. A., Gonsior, M., Bateman, A. P., Nguyen, T. B., Cooper, W. J., and Nizkorodov, S. A.: Appearance of strong absorbers and fluorophores in limonene-
$\mathrm{O}_{3}$ secondary organic aerosol due to $\mathrm{NH}_{4}^{+}$-mediated chemical aging over long time scales, J. Geophys. Res.-Atmos., 115, D05203, doi:10.1029/2009JD012864, 2010.

Bruns, E. A., Perraud, V., Zelenyuk, A., Ezell, M. J., Johnson, S. N., Yu, Y., Imre, D., Finlayson-Pitts, B. J., and Alexander, M. L.: Comparison of ftir and particle mass spectrometry for the measurement of particulate organic nitrates, Environ. Sci. Technol., 44, 1056-1061, doi:10.1021/es9029864, 2010.

Bunce, N. J., Liu, L., Zhu, J., and Lane, D. A.: Reaction of naphthalene and its derivatives with hydroxyl radicals in the gas phase, Environ. Sci. Technol., 31, 2252-2259, doi:10.1021/es960813g, 1997.

Bzdek, B. R., Ridge, D. P., and Johnston, M. V.: Amine exchange into ammonium bisulfate and ammonium nitrate nuclei, Atmos. Chem. Phys., 10, 3495-3503, doi:10.5194/acp-10-3495-2010, 2010.

Cape, J. N., Cornell, S. E., Jickells, T. D., and Nemitz, E.: Organic nitrogen in the atmosphere - Where does it come from? A review of sources and methods, Atmos. Res., 102, 30-48, doi:10.1016/j.atmosres.2011.07.009, 2011.

Cappa, C. D., Onasch, T. B., Massoli, P., Worsnop, D. R., Bates, T. S., Cross, E. S., Davidovits, P., Hakala, J., Hayden, K. L., Jobson, B. T., Kolesar, K. R., Lack, D. A., Lerner, B. M., Li, S.-M., Mellon, D., Nuaaman, I., Olfert, J. S., Petäjä, T., Quinn, P. K., Song, C., Subramanian, R., Williams, E. J., and Zaveri, R. A.: Radiative absorption enhancements due to the mixing state of atmospheric black carbon, Science, 337, 1078-1081, doi:10.1126/science.1223447, 2012.

Chan, L. P. and Chan, C. K.: Displacement of ammonium from aerosol particles by uptake of triethylamine, Aerosol Sci. Tech., 46, 236-247, doi:10.1080/02786826.2011.618815, 2012.

Cheng, Y., Li, S.-M., and Leithead, A.: Chemical characteristics and origins of nitrogen-containing organic compounds in $\mathrm{PM}_{2.5}$ aerosols in the lower fraser valley, Environ. Sci. Technol., 40, 5846-5852, doi:10.1021/es0603857, 2006.

Chhabra, P. S., Flagan, R. C., and Seinfeld, J. H.: Elemental analysis of chamber organic aerosol using an aerodyne high-resolution aerosol mass spectrometer, Atmos. Chem. Phys., 10, 4111-4131, doi:10.5194/acp-10-4111-2010, 2010.

Cornell, S. E., Jickells, T. D., Cape, J. N., Rowland, A. P., and Duce, R. A.: Organic nitrogen deposition on land and coastal environments: a review of methods and data, Atmos. Environ., 37, 2173 2191, doi:10.1016/S1352-2310(03)00133-X, 2003.

Darer, A. I., Cole-Filipiak, N. C., O'Connor, A. E., and Elrod, M. J.: Formation and stability of atmospherically relevant isoprenederived organosulfates and organonitrates, Environ. Sci. Technol., 45, 1895-1902, doi:10.1021/es103797z, 2011.

DeCarlo, P. F., Kimmel, J. R., Trimborn, A., Northway, M. J., Jayne, J. T., Aiken, A. C., Gonin, M., Fuhrer, K., Horvath, T., Docherty, K. S., Worsnop, D. R., and Jimenez, J. L.: Field-deployable, high-resolution, time-of-flight aerosol mass spectrometer, Anal. Chem, 78, 8281-8289, doi:10.1021/ac061249n, 2006.

Donahue, N. M., Henry, K. M., Mentel, T. F., Kiendler-Scharr, A., Spindler, C., Bohn, B., Brauers, T., Dorn, H. P., Fuchs, H., Tillmann, R., Wahner, A., Saathoff, H., Naumann, K.-H., Möhler, O., Leisner, T., Müller, L., Reinnig, M.-C., Hoffmann, T., Salo, K., Hallquist, M., Frosch, M., Bilde, M., Tritscher, T., Barmet, P., Praplan, A. P., DeCarlo, P. F., Dommen, J., Prévôt, A. S. H., and Baltensperger, U.: Aging of biogenic secondary organic aerosol 
via gas-phase $\mathrm{OH}$ radical reactions, P. Natl. Acad. Sci. USA, 109, 13503-13508, doi:10.1073/pnas.1115186109, 2012.

Farina, S. C., Adams, P. J., and Pandis, S. N.: Modeling global secondary organic aerosol formation and processing with the volatility basis set: Implications for anthropogenic secondary organic aerosol, J. Geophys. Res.-Atmos., 115, D09202, doi:10.1029/2009JD013046, 2010.

Farmer, D. K., Matsunaga, A., Docherty, K. S., Surratt, J. D., Seinfeld, J. H., Ziemann, P. J., and Jimenez, J. L.: Response of an aerosol mass spectrometer to organonitrates and organosulfates and implications for atmospheric chemistry, P. Natl. Acad. Sci. USA, 107, 6670-6675, doi:10.1073/pnas.0912340107, 2010.

Flores, J. M., Washenfelder, R. A., Adler, G., Lee, H. J., Segev, L., Laskin, J., Laskin, A., Nizkorodov, S. A., Brown, S. S., and Rudich, Y.: Complex refractive indices in the near-ultraviolet spectral region of biogenic secondary organic aerosol aged with ammonia, Phys. Chem. Chem. Phys., 16, 10629-10642, doi:10.1039/C4CP01009D, 2014.

Friese, E. and Ebel, A.: Temperature dependent thermodynamic model of the system $\mathrm{H}^{+}-\mathrm{NH}_{4}^{+}-\mathrm{Na}^{+}-\mathrm{SO}_{4}^{2-}-\mathrm{NO}_{3}^{-}-\mathrm{Cl}^{-}-\mathrm{H}_{2} \mathrm{O}$, J. Phys. Chem. A., 114, 11595-11631, doi:10.1021/jp101041j, 2010.

Fry, J. L., Kiendler-Scharr, A., Rollins, A. W., Wooldridge, P. J., Brown, S. S., Fuchs, H., Dubé, W., Mensah, A., dal Maso, M., Tillmann, R., Dorn, H.-P., Brauers, T., and Cohen, R. C.: Organic nitrate and secondary organic aerosol yield from $\mathrm{NO}_{3}$ oxidation of $\beta$-pinene evaluated using a gas-phase kinetics/aerosol partitioning model, Atmos. Chem. Phys., 9, 14311449, doi:10.5194/acp-9-1431-2009, 2009.

Fuchs, N. A. and Sutugin, A. G.: Highly dispersed aerosols, butterworth-heinemann, Newton, MA, USA, 1970.

Galloway, M. M., Chhabra, P. S., Chan, A. W. H., Surratt, J. D., Flagan, R. C., Seinfeld, J. H., and Keutsch, F. N.: Glyoxal uptake on ammonium sulphate seed aerosol: reaction products and reversibility of uptake under dark and irradiated conditions, Atmos. Chem. Phys., 9, 3331-3345, doi:10.5194/acp-9-3331-2009, 2009.

García-Gómez, H., Garrido, J. L., Vivanco, M. G., Lassaletta, L., Rábago, I., Àvila, A., Tsyro, S., Sánchez, G., González Ortiz, A., González-Fernández, I., and Alonso, R.: Nitrogen deposition in Spain: Modeled patterns and threatened habitats within the Natura 2000 network, Sci. Total Environ., 485-486, 450-460, doi:10.1016/j.scitotenv.2014.03.112, 2014.

Gross, D. S., Gälli, M. E., Kalberer, M., Prevot, A. S. H., Dommen, J., Alfarra, M. R., Duplissy, J., Gaeggeler, K., Gascho, A., Metzger, A., and Baltensperger, U.: Real-time measurement of oligomeric species in secondary organic aerosol with the aerosol time-of-flight mass spectrometer, Anal. Chem., 78, 2130-2137, doi:10.1021/ac0601381, 2006.

Hallquist, M., Wenger, J. C., Baltensperger, U., Rudich, Y., Simpson, D., Claeys, M., Dommen, J., Donahue, N. M., George, C., Goldstein, A. H., Hamilton, J. F., Herrmann, H., Hoffmann, T., Iinuma, Y., Jang, M., Jenkin, M. E., Jimenez, J. L., Kiendler-Scharr, A., Maenhaut, W., McFiggans, G., Mentel, Th. F., Monod, A., Prévôt, A. S. H., Seinfeld, J. H., Surratt, J. D., Szmigielski, R., and Wildt, J.: The formation, properties and impact of secondary organic aerosol: current and emerging issues, Atmos. Chem. Phys., 9, 5155-5236, doi:10.5194/acp-9-51552009, 2009.
Hawkins, L. N., Russell, L. M., Covert, D. S., Quinn, P. K., and Bates, T. S.: Carboxylic acids, sulfates, and organosulfates in processed continental organic aerosol over the southeast Pacific Ocean during VOCALS-REx 2008, J. Geophys. Res.-Atmos., 115, D13201, doi:10.1029/2009jd013276, 2010.

Heald, C. L., Collett Jr., J. L., Lee, T., Benedict, K. B., Schwandner, F. M., Li, Y., Clarisse, L., Hurtmans, D. R., Van Damme, M., Clerbaux, C., Coheur, P.-F., Philip, S., Martin, R. V., and Pye, H. O. T.: Atmospheric ammonia and particulate inorganic nitrogen over the United States, Atmos. Chem. Phys., 12, 10295-10312, doi:10.5194/acp-12-10295-2012, 2012.

Iinuma, Y., Ge, O. B., Kahnt, A., and Herrmann, H.: Laboratory chamber studies on the formation of organosulfates from reactive uptake of monoterpene oxides, Phys. Chem. Chem. Phys., 11, 7985-7997, doi:10.1039/b904025k, 2009.

IPCC: Climate Change 2013: The physical science basis, Contribution of working group I to the fifth assessment report of the Intergovernmental Panel on Climate Change, edited by: Stocker, T. F., Qin, D., Plattner, G.-K., Tignor, M., Allen, S. K., Boschung, J., Nauels, A., Xia, Y., Bex, V. and Midgley, P. M., Cambridge University Press, Cambridge, UK and New York, NY, USA, 2013.

Kalberer, M., Paulsen, D., Sax, M., Steinbacher, M., Dommen, J., Prevot, A. S. H., Fisseha, R., Weingartner, E., Frankevich, V., Zenobi, R., and Baltensperger, U.: Identification of polymers as major components of atmospheric organic aerosols, Science, 303, 1659-1662, doi:10.1126/science.1092185, 2004.

Kinsey, J. S., Hays, M. D., Dong, Y., Williams, D. C., and Logan, R.: Chemical characterization of the fine particle emissions from commercial aircraft engines during the Aircraft Particle Emissions Experiment (APEX) 1 to 3, Environ. Sci. Technol., 45, 3415-3421, doi:10.2514/1.36371, 2011.

Kosterev, A. A., Curl, R. F., Tittel, F. K., Kohler, R., Gmachl, C., Capasso, F., Sivco, D. L., and Cho, A. Y.: Transportable automated ammonia sensor based on a pulsed thermoelectrically cooled quantum-cascade distributed feedback laser, Appl. Optics, 41, 573-578, doi:10.1364/ao.41.000573, 2002.

Kourtchev, I., O’Connor, I. P., Giorio, C., Fuller, S. J., Kristensen, K., Maenhaut, W., Wenger, J. C., Sodeau, J. R., Glasius, M., and Kalberer, M.: Effects of anthropogenic emissions on the molecular composition of urban organic aerosols: An ultrahigh resolution mass spectrometry study, Atmos. Environ., 89, 525-532, doi:10.1016/j.atmosenv.2014.02.051, 2014.

Kuwata, M. and Martin, S. T.: Phase of atmospheric secondary organic material affects its reactivity, P. Natl. Acad. Sci. USA, 109, 17354-17359, doi:10.1073/pnas.1209071109, 2012.

Kwamena, N.-O. A., Thornton, J. A., and Abbatt, J. P. D.: Kinetics of surface-bound benzo[a]pyrene and ozone on solid organic and salt aerosols, J. Phys. Chem. A., 108, 11626-11634, doi:10.1021/jp046161x, 2004.

Laskin, A., Laskin, J., and Nizkorodov, S. A.: Chemistry of atmospheric brown carbon, Chem. Rev., 115, 4335-4382, doi:10.1021/cr5006167, 2015.

Laskin, J., Laskin, A., Roach, P. J., Slysz, G. W., Anderson, G. A., Nizkorodov, S. A., Bones, D. L., and Nguyen, L. Q.: Highresolution desorption electrospray ionization mass spectrometry for chemical characterization of organic aerosols, Anal. Chem., 82, 2048-2058, doi:10.1021/ac902801f, 2010.

Laskin, J., Laskin, A., Nizkorodov, S. A., Roach, P., Eckert, P., Gilles, M. K., Wang, B., Lee, H. J., and Hu, Q.: Molecular se- 
lectivity of brown carbon chromophores, Environ. Sci. Technol., 48, 12047-12055, doi:10.1021/es503432r, 2014.

Lee, A. K. Y., Zhao, R., Li, R., Liggio, J., Li, S.-M., and Abbatt, J. P. D.: Formation of light absorbing organo-nitrogen species from evaporation of droplets containing glyoxal and ammonium sulfate, Environ. Sci. Technol., 47, 12819-12826, doi:10.1021/es402687w, 2013.

Lee, H. J., Laskin, A., Laskin, J., and Nizkorodov, S. A.: Excitation emission spectra and fluorescence quantum yields for fresh and aged biogenic secondary organic aerosols, Environ. Sci. Technol., 47, 5763-5770, doi:10.1021/es400644c, 2013.

Lee, H. J., Aiona, P. K., Laskin, A., Laskin, J., and Nizkorodov, S. A.: Effect of solar radiation on the optical properties and molecular composition of laboratory proxies of atmospheric brown carbon, Environ. Sci. Technol., 48, 10217-10226, doi:10.1021/es502515r, 2014.

Lelieveld, J. and Crutzen, P. J.: The role of clouds in tropospheric photochemistry, J. Atmos. Chem., 12, 229-267, doi:10.1007/BF00048075, 1991.

Liggio, J. and Li, S. M.: Reactive uptake of pinonaldehyde on acidic aerosols, J. Geophys. Res.-Atmos., 111, D24303, doi:10.1029/2005JD006978, 2006a.

Liggio, J. and Li, S. M.: Organosulfate formation during the uptake of pinonaldehyde on acidic sulfate aerosols, Geophys. Res. Lett., 33, L13808, doi:10.1029/2006GL026079, 2006b.

Liggio, J. and Li, S.-M.: Reversible and irreversible processing of biogenic olefins on acidic aerosols, Atmos. Chem. Phys., 8, 2039-2055, doi:10.5194/acp-8-2039-2008, 2008.

Liggio, J., Li, S. M., and McLaren, R.: Heterogeneous reactions of glyoxal on particulate matter: Identification of acetals and sulfate esters, Environ. Sci. Technol., 39, 1532-1541, doi:10.1021/es048375y, 2005a.

Liggio, J., Li, S. M., and McLaren, R.: Reactive uptake of glyoxal by particulate matter, J. Geophys. Res.-Atmos., 110, D10304, doi:10.1029/2004jd005113, 2005b.

Liggio, J., Li, S.-M., Vlasenko, A., Stroud, C., and Makar, P.: Depression of ammonia uptake to sulfuric acid aerosols by competing uptake of ambient organic gases, Environ. Sci. Technol., 45, 2790-2796, doi:10.1021/es103801g, 2011.

Lightstone, J. M., Onasch, T. B., Imre, D., and Oatis, S.: Deliquescence, efflorescence, and water activity in ammonium nitrate and mixed ammonium nitrate/succinic acid microparticles, J. Phys. Chem. A., 104, 9337-9346, doi:10.1021/jp002137h, 2000.

Lin-Vien, D., Colthup, N. B., Fateley, W. G., and Grasselli, J. G.: The handbook of infrared and raman characteristic frequencies of organic molecules, A Division of Harcourt Brace \& Company 525 B Street, Suite 1900, San Diego, California 92101-4495, USA, 1991.

Liu, X., Zhang, Y., Han, W., Tang, A., Shen, J., Cui, Z., Vitousek, P., Erisman, J. W., Goulding, K., Christie, P., Fangmeier, A., and Zhang, F.: Enhanced nitrogen deposition over China, Nature, 494, 459-462, doi:10.1038/nature11917, 2013.

Liu, Y., Han, C., Liu, C., Ma, J., Ma, Q., and He, H.: Differences in the reactivity of ammonium salts with methylamine, Atmos. Chem. Phys., 12, 4855-4865, doi:10.5194/acp-12-48552012, 2012a.

Liu, Y., Ma, Q., and He, H.: Heterogeneous uptake of amines by citric acid and humid acid, Environ. Sci Technol., 46, 1111211118, doi:10.1021/es302414v, 2012b.
Loza, C. L., Chhabra, P. S., Yee, L. D., Craven, J. S., Flagan, R. C., and Seinfeld, J. H.: Chemical aging of $m$-xylene secondary organic aerosol: laboratory chamber study, Atmos. Chem. Phys., 12, 151-167, doi:10.5194/acp-12-151-2012, 2012.

Ma, J., Liu, Y., and He, H.: Degradation kinetics of anthracene by ozone on mineral oxides, Atmos. Environ., 44, 4446-4453, doi:10.1016/j.atmosenv.2010.07.042, 2010

Ma, Y., Brooks, S. D., Vidaurre, G., Khalizov, A. F., Wang, L., and Zhang, R.: Rapid modification of cloud-nucleating ability of aerosols by biogenic emissions, Geophys. Res. Lett., 40, 6293 6297, doi:10.1002/2013GL057895, 2013.

Massman, W. J.: A Review of the molecular diffusivtives of $\mathrm{H}_{2} \mathrm{O}, \mathrm{CO}_{2}, \mathrm{CH}_{4}, \mathrm{CO}, \mathrm{O}_{3}, \mathrm{SO}_{2}, \mathrm{NH}_{3}, \mathrm{~N}_{2} \mathrm{O}, \mathrm{NO}$, and $\mathrm{NO}_{2}$ in air, $\mathrm{O}_{2}$ and $\mathrm{N}_{2}$ near STP, Atmos. Environ., 32, 1111-1127, doi:10.1016/S1352-2310(97)00391-9, 1998.

Miller, F. A. and Wilkins, C. H.: Infrared spectra and characteristic frequencies of inorganic ions, Anal. Chem., 24, 1253-1294, doi:10.1021/ac60068a007, 1952.

Mitsumori, S., Zhang, H., Cheong, P. H. Y., Houk, K. N., Tanaka, F., and Barbas, C. F.: Direct asymmetric anti-Mannich-Type reactions catalyzed by a designed amino acid, J. Am. Chem. Soc., 128, 1040-1041, doi:10.1021/ja056984f, 2006.

Mmereki, B. T. and Donaldson, D. J.: Direct observation of the kinetics of an atmospherically important reaction at the air-aqueous interface, J. Phys. Chem. A, 107 11038-11042, doi:10.1021/jp036119m, 2003

Moise, T., Flores, J. M., and Rudich, Y.: Optical properties of secondary organic aerosols and their changes by chemical processes, Chem. Rev., 115, 4400-4439, doi:10.1021/cr5005259, 2015.

Na, K., Song, C., Switzer, C., and Cocker, D. R.: Effect of ammonia on secondary organic aerosol formation from $\alpha$-pinene ozonolysis in dry and humid conditions, Environ. Sci. Technol., 41, 6096-6102, doi:10.1021/es061956y, 2007.

Nguyen, Q. T., Kristensen, T. B., Hansen, A. M. K., Skov, H., Bossi, R., Massling, A., Sorensen, L. L., Bilde, M., Glasius, M., and Nojgaard, J. K.: Characterization of humic-like substances in Arctic aerosols, J. Geophys. Res.-Atmos., 119, 5011-5027, doi:10.1002/2013jd020144, 2014.

Nguyen, T. B., Lee, P. B., Updyke, K. M., Bones, D. L., Laskin, J., Laskin, A., and Nizkorodov, S. A.: Formation of nitrogenand sulfur-containing light-absorbing compounds accelerated by evaporation of water from secondary organic aerosols, J. Geophys. Res.-Atmos., 117, D01207, doi:10.1029/2011JD016944, 2012.

Nguyen, T. B., Laskin, A., Laskin, J., and Nizkorodov, S. A.: Brown carbon formation from ketoaldehydes of biogenic monoterpenes, Faraday Discuss., 165, 473-494, doi:10.1039/C3FD00036B, 2013.

Paciga, A. L., Riipinen, I., and Pandis, S. N.: Effect of Ammonia on the Volatility of Organic Diacids, Environ. Sci. Technol., 48, 13769-13775, doi:10.1021/es5037805, 2014.

Pöschl, U., Letzel, T., Schauer, C., and Niessner, R.: Interaction of ozone and water vapor with spark discharge soot aerosol particles coated with benzo[a]pyrene: $\mathrm{O}_{3}$ and $\mathrm{H}_{2} \mathrm{O}$ adsorption, benzo[a]pyrene degradation, and atmospheric implications, J. Phys. Chem. A, 105, 4029-4041, doi:10.1021/jp004137n, 2001.

Powelson, M. H., Espelien, B. M., Hawkins, L. N., Galloway, M. M., and Haan, D. O. D.: Brown carbon formation by aqueous-phase carbonyl compound reactions with amines 
and ammonium sulfate, Environ. Sci. Technol., 48, 985-993, doi:10.1021/es4038325, 2014.

Qiu, C., Wang, L., Lal, V., Khalizov, A. F., and Zhang, R.: Heterogeneous reactions of alkylamines with ammonium sulfate and ammonium bisulfate, Environ. Sci Technol., 45, 4748-4755, doi:10.1021/es1043112, 2011.

Reis, S., Pinder, R. W., Zhang, M., Lijie, G., and Sutton, M. A.: Reactive nitrogen in atmospheric emission inventories, Atmos. Chem. Phys., 9, 7657-7677, doi:10.5194/acp-9-7657-2009, 2009.

Russell, L. M., Bahadur, R., and Ziemann, P. J.: Identifying organic aerosol sources by comparing functional group composition in chamber and atmospheric particles, P. Natl. Acad. Sci. USA, 108, 3516-3521, doi:10.1073/pnas.1006461108, 2011.

Saleh, R., Hennigan, C. J., McMeeking, G. R., Chuang, W. K., Robinson, E. S., Coe, H., Donahue, N. M., and Robinson, A. L.: Absorptivity of brown carbon in fresh and photo-chemically aged biomass-burning emissions, Atmos. Chem. Phys., 13, 76837693, doi:10.5194/acp-13-7683-2013, 2013.

Salma, I., Mészáros, T., Maenhaut, W., Vass, E., and Majer, Z.: Chirality and the origin of atmospheric humic-like substances, Atmos. Chem. Phys., 10, 1315-1327, doi:10.5194/acp-10-13152010, 2010.

Sareen, N., Moussa, S. G., and McNeill, V. F.: Photochemical aging of light-absorbing secondary organic aerosol material, J. Phys. Chem. A, 117, 2987-2996, 2013.

Shilling, J. E., Chen, Q., King, S. M., Rosenoern, T., Kroll, J. H., Worsnop, D. R., DeCarlo, P. F., Aiken, A. C., Sueper, D., Jimenez, J. L., and Martin, S. T.: Loading-dependent elemental composition of $\alpha$-pinene SOA particles, Atmos. Chem. Phys., 9, 771-782, doi:10.5194/acp-9-771-2009, 2009.

Souza, K. F., Carvalho, L. R. F., Allen, A. G., and Cardoso, A. A.: Diurnal and nocturnal measurements of PAH, nitro-PAH, and oxy-PAH compounds in atmospheric particulate matter of a sugar cane burning region, Atmos. Environ., 83, 193-201, doi:10.1016/j.atmosenv.2013.11.007, 2014.

Sun, Y.-L., Zhang, Q., Schwab, J. J., Demerjian, K. L., Chen, W.N., Bae, M.-S., Hung, H.-M., Hogrefe, O., Frank, B., Rattigan, O. V., and Lin, Y.-C.: Characterization of the sources and processes of organic and inorganic aerosols in New York city with a high-resolution time-of-flight aerosol mass apectrometer, Atmos. Chem. Phys., 11, 1581-1602, doi:10.5194/acp-11-15812011, 2011.

Surratt, J. D., Kroll, J. H., Kleindienst, T. E., Edney, E. O., Claeys, M., Sorooshian, A., Ng, N. L., Offenberg, J. H., Lewandowski, M., Jaoui, M., Flagan, R. C., and Seinfeld, J. H.: Evidence for organosulfates in secondary organic aerosol, Environ. Sci. Technol., 41, 517-527, doi:10.1021/es062081q, 2006.

Swartz, E., Shi, Q., Davidovits, P., Jayne, J. T., Worsnop, D. R., and Kolb, C. E.: Uptake of gas-phase ammonia. 2. uptake by sulfuric acid surfaces, J. Phys. Chem. A., 103, 8824-8833, doi:10.1021/jp991697h, 1999.

Trainic, M., Abo Riziq, A., Lavi, A., Flores, J. M., and Rudich, Y.: The optical, physical and chemical properties of the products of glyoxal uptake on ammonium sulfate seed aerosols, Atmos. Chem. Phys., 11, 9697-9707, doi:10.5194/acp-11-96972011, 2011.

Updyke, K. M., Nguyen, T. B., and Nizkorodov, S. A.: Formation of brown carbon via reactions of ammonia with secondary or- ganic aerosols from biogenic and anthropogenic precursors, Atmos. Environ., 63, 22-31, doi:10.1016/j.atmosenv.2012.09.012, 2012.

Varutbangkul, V., Brechtel, F. J., Bahreini, R., Ng, N. L., Keywood, M. D., Kroll, J. H., Flagan, R. C., Seinfeld, J. H., Lee, A., and Goldstein, A. H.: Hygroscopicity of secondary organic aerosols formed by oxidation of cycloalkenes, monoterpenes, sesquiterpenes, and related compounds, Atmos. Chem. Phys., 6, 23672388, doi:10.5194/acp-6-2367-2006, 2006.

Wang, K., Ge, M., and Wang, W.: Kinetics of the gas-phase reactions of 5-hexen-2-one with $\mathrm{OH}$ and $\mathrm{NO}_{3}$ radicals and $\mathrm{O}_{3}$, Chem. Phys. Lett., 490, 29-33, doi:10.1016/j.cplett.2010.03.023, 2010.

Wang, X. F., Gao, S., Yang, X., Chen, H., Chen, J. M., Zhuang, G. S., Surratt, J. D., Chan, M. N., and Seinfeld, J. H.: Evidence for high molecular weight nitrogen-containing organic salts in urban aerosols, Environ. Sci. Technol., 44, 4441-4446, doi:10.1021/es1001117, 2010.

Widmann, J. F. and Davis, E. J.: Mathematical models of the uptake of $\mathrm{ClONO}_{2}$ and other gases by atmospheric aerosols, J. Aerosol Sci., 28, 87-106, doi:10.1016/S0021-8502(96)00060-2, 1997.

Worsnop, D. R., Morris, J. W., Shi, Q., Davidovits, P., and Kolb, C. E.: A chemical kinetic model for reactive transformations of aerosol particles, Geophys. Res. Lett., 29, 1996, doi:10.1029/2002g1015542, 2002.

Wu, H. B., Chan, M. N., and Chan, C. K.: FTIR characterization of polymorphic transformation of ammonium nitrate, Aerosol Sci.Technol., 41, 581-588, doi:10.1080/02786820701272038, 2007.

Yu, G., Bayer, A. R., Galloway, M. M., Korshavn, K. J., Fry, C. G., and Keutsch, F. N.: Glyoxal in aqueous ammonium sulfate solutions: Products, kinetics and hydration effects, Environ. Sci. Technol., 45, 6336-6342, doi:10.1021/es200989n, 2011.

Yu, J., Cocker III, D., Griffin, R., Flagan, R., and Seinfeld, J.: Gas-phase ozone oxidation of monoterpenes: gaseous and particulate products, J. Atmos. Chem., 34, 207-258, doi:10.1023/a:1006254930583, 1999.

Zarzana, K. J., De Haan, D. O., Freedman, M. A., Hasenkopf, C. A., and Tolbert, M. A.: Optical properties of the products of $\alpha$-dicarbonyl and amine reactions in simulated cloud droplets, Environ. Sci. Technol., 46, 4845-4851, doi:10.1021/es2040152, 2012.

Zhang, D. and Zhang, R.: Ozonolysis of a-pinene and b-pinene: Kinetics and mechanism, J. Chem. Phys., 122, 114308-114319, doi:10.1063/1.1862616, 2005.

Zhang, R., Wang, G., Guo, S., Zamora, M. L., Ying, Q., Lin, Y., Wang, W., Hu, M., and Wang, Y.: Formation of urban fine particulate matter, Chem. Rev., 115, 3803-3855, doi:10.1021/acs.chemrev.5b00067, 2015.

Zhao, J., Zhang, R., Misawa, K., and Shibuya, K.: Experimental product study of the $\mathrm{OH}$-initiated oxidation of m-xylene, J. Photoch. Photobio. A, 176, 199-207, doi:10.1016/j.jphotochem.2005.07.013, 2005.

Zhao, R., Lee, A. K. Y., Huang, L., Li, X., Yang, F., and Abbatt, J. P. D.: Photochemical processing of aqueous atmospheric brown carbon, Atmos. Chem. Phys., 15, 6087-6100, doi:10.5194/acp15-6087-2015, 2015. 